\title{
Revision and update of the Callovian-Ryazanian Stratigraphic Nomenclature in the northern Dutch offshore, i.e. Central Graben Subgroup and Scruff Group
}

\author{
D.K. Munsterman ${ }^{*}$, R.M.C.H. Verreussel, H.F. Mijnlieff, N. Witmans, S. Kerstholt-Boegehold \& \\ 0.A. Abbink
}

TN0 - Geological Survey of the Netherlands, P.0. Box 80015, 3508 TA Utrecht, the Netherlands.

* Corresponding author. Email: dirk.munsterman@tno.nl.

Manuscript received: June 2011, accepted: November 2011

\begin{abstract}
Exploration in a mature basin requires a detailed classification and standardisation of rock stratigraphy to adequately comprehend the depositional history and prospect architecture. The pre-Quaternary Stratigraphic Nomenclature of the Netherlands compiled by Van Adrichem Boogaert \& Kouwe in 1993 provided a consistent framework for use by the Dutch geological community. Over the past twenty years, new biostratigraphic techniques and continued exploration in the Netherlands have provided additional stratigraphic information. Based on this information the Late Jurassic lithostratigraphy in particular, shows significant inaccuracies. The Callovian-Ryazanian strata from the northern offshore of the Netherlands' territorial waters, termed the Central Graben Subgroup and Scruff Group, reveal a complex sedimentary history. The combination of non-marine to shallow marine lateral facies changes, repetitive log and facies characteristics in time, sea-level and climate change, salt tectonics and structural compartmentalisation hamper straightforward seismic interpretation and log correlation. Recognition of three genetic sequences by Abbink et al. in 2006 enabled an improved reconstruction of the geological history. Further improvements in refinement and reliability of the stratigraphy together with new information on the facies and ages of the successions and about the subsequent tectonostratigraphic development of the northern Dutch offshore area form the basis of the present revision. As a result, earlier lithostratigraphic models have been changed and new lithostratigraphic relationships and names are introduced in this paper.
\end{abstract}

Keywords: Dutch offshore, Late Jurassic, stratigraphy, nomenclature

\section{Introduction}

Lithostratigraphy describes and defines rock units based on lithological characteristics. This in contrast to biostratigraphy which is based on the fossil content of rock units. The combination of both litho- and biostratigraphy describes the spatial and temporal relationships between rock units and is fundamental to an adequate understanding of geologic history. Existing Late Jurassic stratigraphy was established in 1980 when NAM and RGD published the 'Stratigraphic Nomenclature of the Netherlands'. Van Adrichem Boogaert and Kouwe revised the standard in 1993 (Fig. 1). The lithostratigraphical classification was based on various regional publications of the Upper Jurassic, e.g. by Brown in Glennie (1990), Cameron et al. (1992), Frandsen et al. (1987), Herngreen \& Wong (1989), Herngreen et al. (1991),
Michelson \& Wong (1991) and Ziegler (1990). New data gathered from continued exploration in the Dutch Central Graben and adjacent Terschelling Basin during the past twenty years resulted in an improved understanding of the latest Middle Jurassic to earliest Cretaceous, Callovian-Ryazanian (later referred to as Late Jurassic), siliciclastic successions. Several studies contributed to this progress, e.g.: Abbink et al. (2006), Herngreen et al. (2000, 2003), Duin et al. (2006), Wong (2007), Andsbjerg \& Dybkjaer (2003), Michelsen et al. (2003), Johannessen (2003), Fraser et al. (2003), Coward et al. (2003) and Lott et al. (2010). New palynological techniques (e.g. Sporomorph Ecogroups in Abbink, 1998) and newly acquired sedimentological, lithological, stratigraphic and seismic data led to the identification of three well recognisable unconformities or their correlatable conformities in the late Middle Jurassic to earliest Cretaceous. 


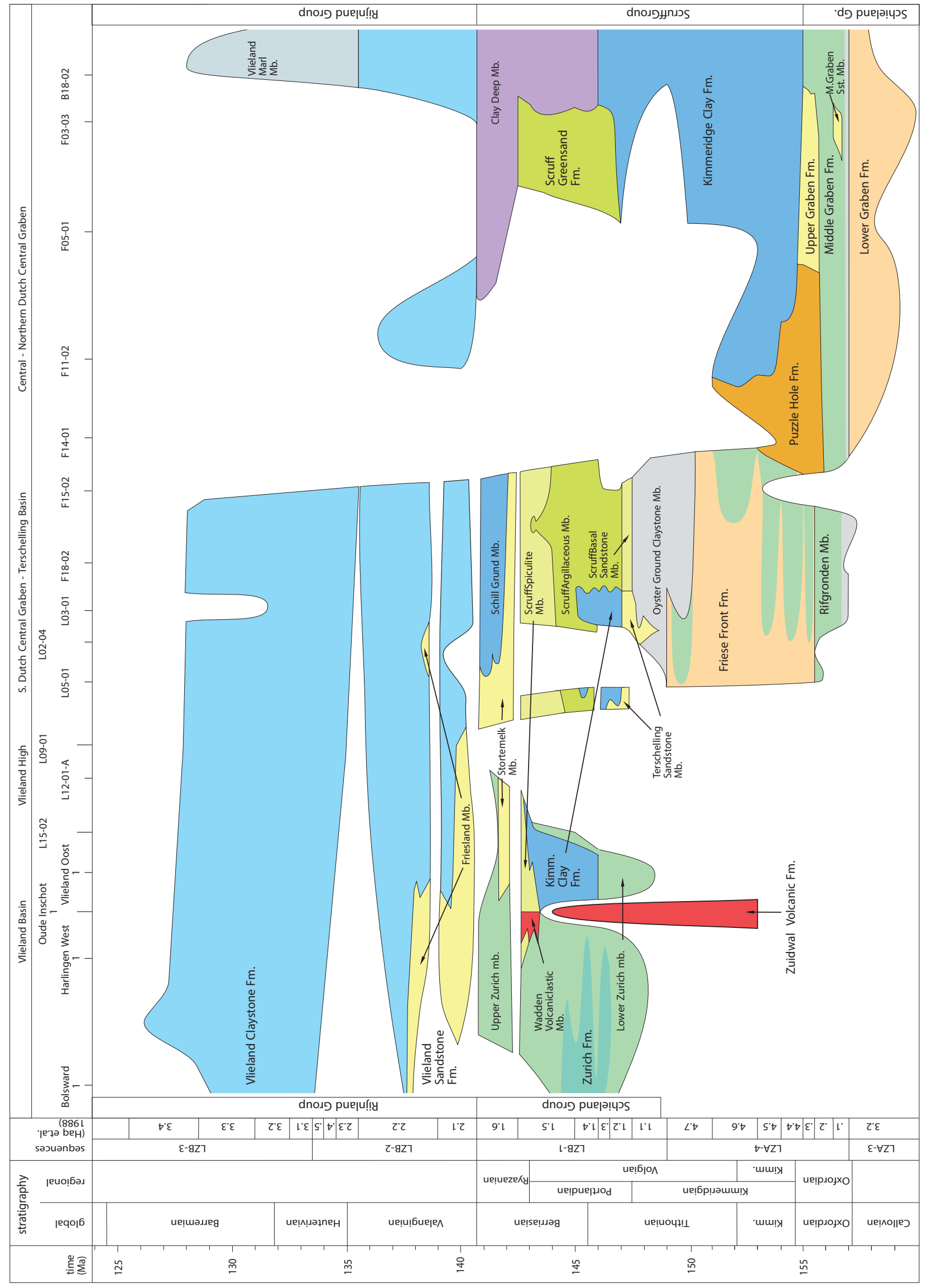

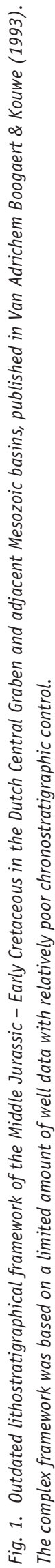




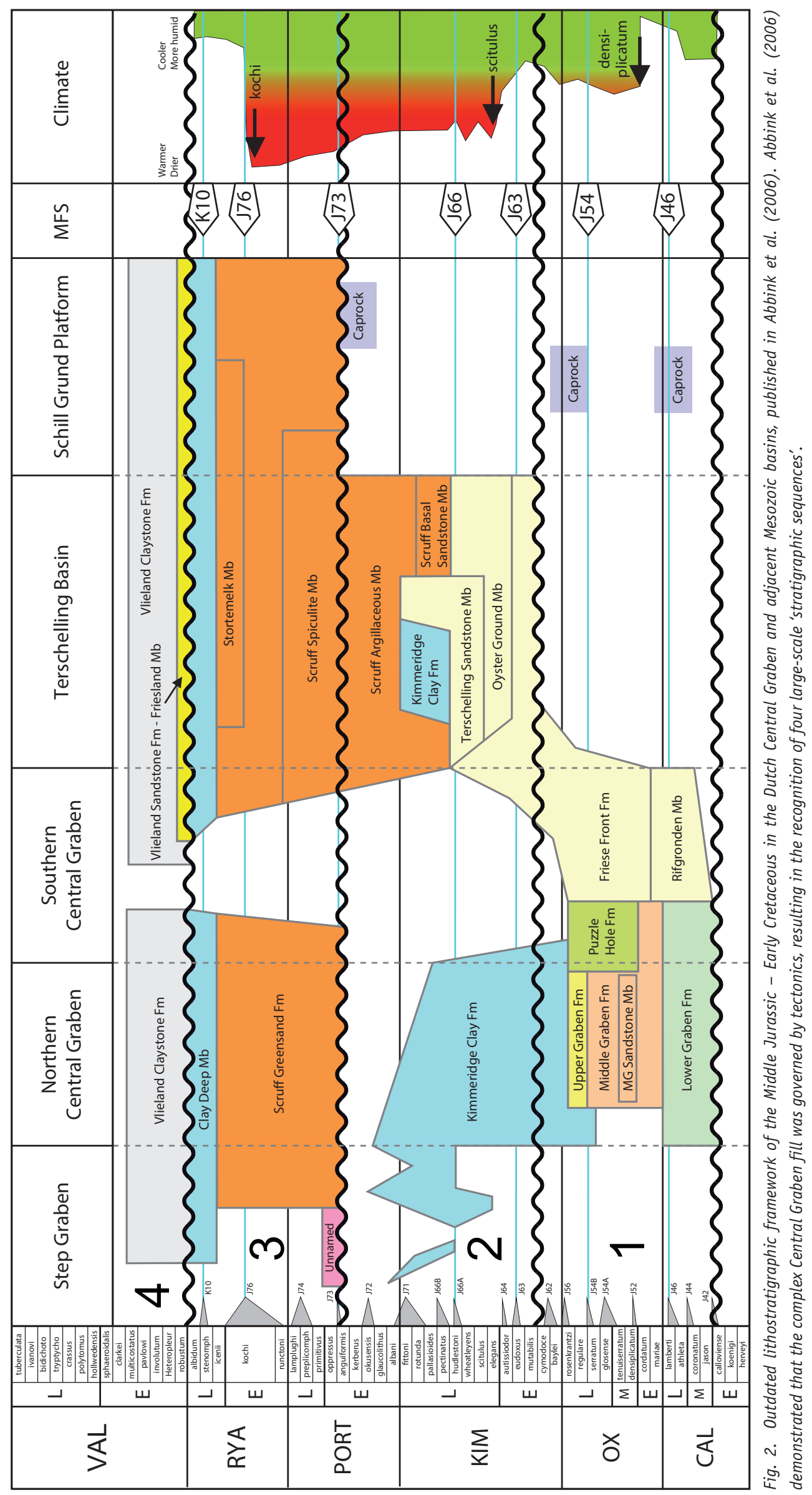

Netherlands Journal of Geosciences — Geologie en Mijnbouw | 91 - 4 | 2012 
These events resulted in the classification of three major stratigraphic sequences in the Late Jurassic and one in the overlying earliest Cretaceous interval, which are related to tectonic, climatic, environmental and stratigraphic development (Abbink et al., 2006; Fig. 2). The recognition of these sequences in wells in the Central Graben and Terschelling Basin showed the present lithostratigraphic scheme to be outdated and inadequate for consistent stratigraphic interpretation. Hence the necessity arose to revise and update the Late Jurassic succession of the Stratigraphic Nomenclature for the subsurface of the northern Dutch offshore area. In order to reach broad acceptance and a general consensus, cooperation was sought and obtained from the E\&P industry and consultants. The past two years a series of workshops and (inter)national presentations were organised on this topic. The recommendations from these meetings and discussions afterwards are integrated in the present contribution.

\section{Geological setting}

The Permian, Triassic and Early Jurassic were periods of relative quiescence in the Netherlands (De Jager, 2007). During the Triassic, a rifting phase related to the Mesozoic break-up of the Pangea supercontinent commenced in the Artic-North Atlantic and between Greenland and Scandinavia (Lott et al., 2010). During the Jurassic, an eastern branch of the incipient rift basins/structures protruded into the North Sea area (Ziegler $1988,1990)$. As such the structural outline of the Netherlands progressively changed from a single large basin, the Southern Permian Basin, into a multi-basinal pattern during the Late Jurassic (Wong, 2007; Fig. 3).

The slow regional subsidence in pre-rift (Early Jurassic) times led to the accumulation of the mainly marine argillaceous deposits of the Altena Group. In general, regional extension was east-west directed. An uplift phase ended the supposed largely uniform subsidence and sheet-like deposition of Middle Jurassic sediments. This uplift, related to the development of a thermal dome in the central North Sea area during the Aalenian to Bathonian (Mid-Kimmerian tectonic phase), caused widespread erosion and non-deposition (Underhill \& Partington, 1993; Andsbjerg \& Dybkjaer, 2003). It created a hiatus between the Late Jurassic and underlying Middle to Early Jurassic or older strata in the northern Dutch offshore (Fig. 1). In the Middle Callovian, rifting starts again and continues until the base of the Valanginian. At first, rifting only affected the relatively narrow area of the graben axis. This phase is referred to as Sequence 1 in Abbink et al. (2006). During the Early Kimmeridgian, a change in the tectonic regime occurs in the southern North Sea. Extension direction changes from E-W to SW-NE (Zanella \& Coward, 2003). Numerous old lineaments/ structures were rejuvenated (see structural elements in Fig. 4), which resulted in the opening of the Terschelling Basin and the Step Graben and initiates the end of subsidence in some parts

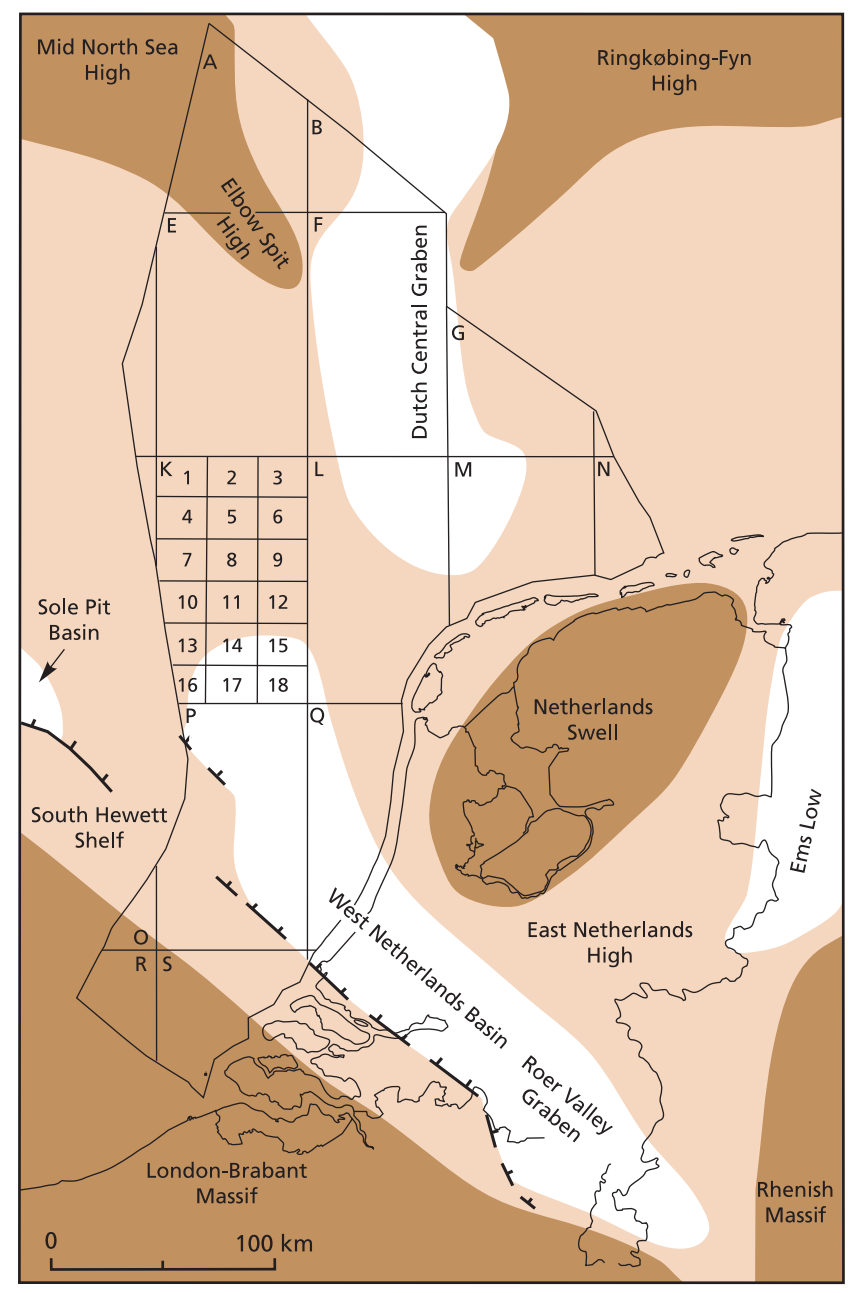

Fig. 3. Map of latest Triassic to Middle Jurassic structural elements (after Van Adrichem Boogaert \& Kouwe, 1993; Wong, 2007). Dark brown colour: structural high, partly subaerial landmass; light brown colour: platform, intermittently flooded; white: basin.

of the Central Graben. This phase is referred to as Sequence 2 in Abbink et al. (2006). During this phase, the Terschelling Basin was filled with locally more than $2000 \mathrm{~m}$ thick siliciclastic deposits belonging to the predominantly non-marine Schieland Group and the marine Scruff Group (e.g. Duin et al., 2006). During the next phase, adjacent platforms, like the Schill Grund and Cleaver Bank Platforms were flooded. This phase, occurring around the Jurassic-Cretaceous boundary, is referred to as Sequence 3 in Abbink et al. (2006). Sequences 2 and 3 are relatively thick in the Terschelling Basin as compared to the Central Graben. Moreover, a hiatus occurs in the Central Graben, but deposition was continuous in the depocentre of the Terschelling Basin (Abbink et al., 2006). In the Early Cretaceous, at the end of the Ryazanian, rifting came to a halt. Fault activity in the Graben area gradually ceased and the succeeding shallow marine sandstones and shales of the Early Cretaceous Rijnland Group effectively blanket the former graben and platform areas. From then on, the southern North Sea basin is subjected to thermal subsidence. 


\section{Current lithostratigraphy}

The Late Jurassic sediments of the northern Dutch offshore are subdivided into the Schieland and the Scruff groups. These groups are further differentiated in numerous formations and members (see Table 1). The Zuidwal Volcanic Formation (locally known from the Vlieland Basin), comprising massive volcanic rocks, brecciated volcanoclastic sediments is not assigned to a group (Van Adrichem Boogaert \& Kouwe, 1993; see Fig. 1). A brief overview of these lithostratigraphical groups is presented below.

\section{Schieland Group}

This group comprises all predominantly continental Late Jurassic and Early Cretaceous successions. It is subdivided into the Central Graben and Delfland Subgroup (Table 1). This distinction is based on the (structural) geographical setting.

The Central Graben Subgroup covers the lithostratigraphical subunits of the Schieland Group that are restricted to the Dutch Central Graben and Terschelling Basin (Fig. 4). The Central Graben Subgroup consists of an alternation of sandstones, claystones and coal beds. A maximum thickness of approximately $1100 \mathrm{~m}$ is attained in the F quadrant (e.g. in the F03 and F11 blocks). It is subdivided into five formations: Lower Graben,
Middle Graben, Upper Graben, Puzzle Hole and Friese Front formations (Fig. 1). The age of the Central Graben Subgroup ranges from the Middle Callovian to Kimmeridgian.

The Delfland Subgroup is exclusively present in the Jurassic-Cretaceous basins south of the Central Graben and Terschelling basins, such as in the Broad Fourteens Basin. In the northern Dutch offshore the Delfland Subgroup only comprises the Zurich Formation in the Vlieland Basin (Figs 1 and 4). The Zurich Formation is defined by sandy to silty mudstones with intercalated sands, carbonates and coal beds. The thickest Zurich Formation accumulation recorded is approximately $300 \mathrm{~m}$ (well Zurich Waddenzee-1).

\section{Scruff Group}

The Scruff Group encompasses all predominantly marine formations from the Dutch Central Graben, Terschelling Basin and northern part of the Vlieland Basin. The Scruff Group is absent in the Broad Fourteens and West Netherlands basins. It consists of locally bituminous claystones with intercalated carbonate beds, and of glauconitic, sometimes argillaceous, sandstones. It is subdivided into the Kimmeridge Clay and Scruff Greensand formations. The thickest successions reach nearly $900 \mathrm{~m}$ (e.g. in well F03-3). The group is dated Late 0xfordian-Late Ryazanian.

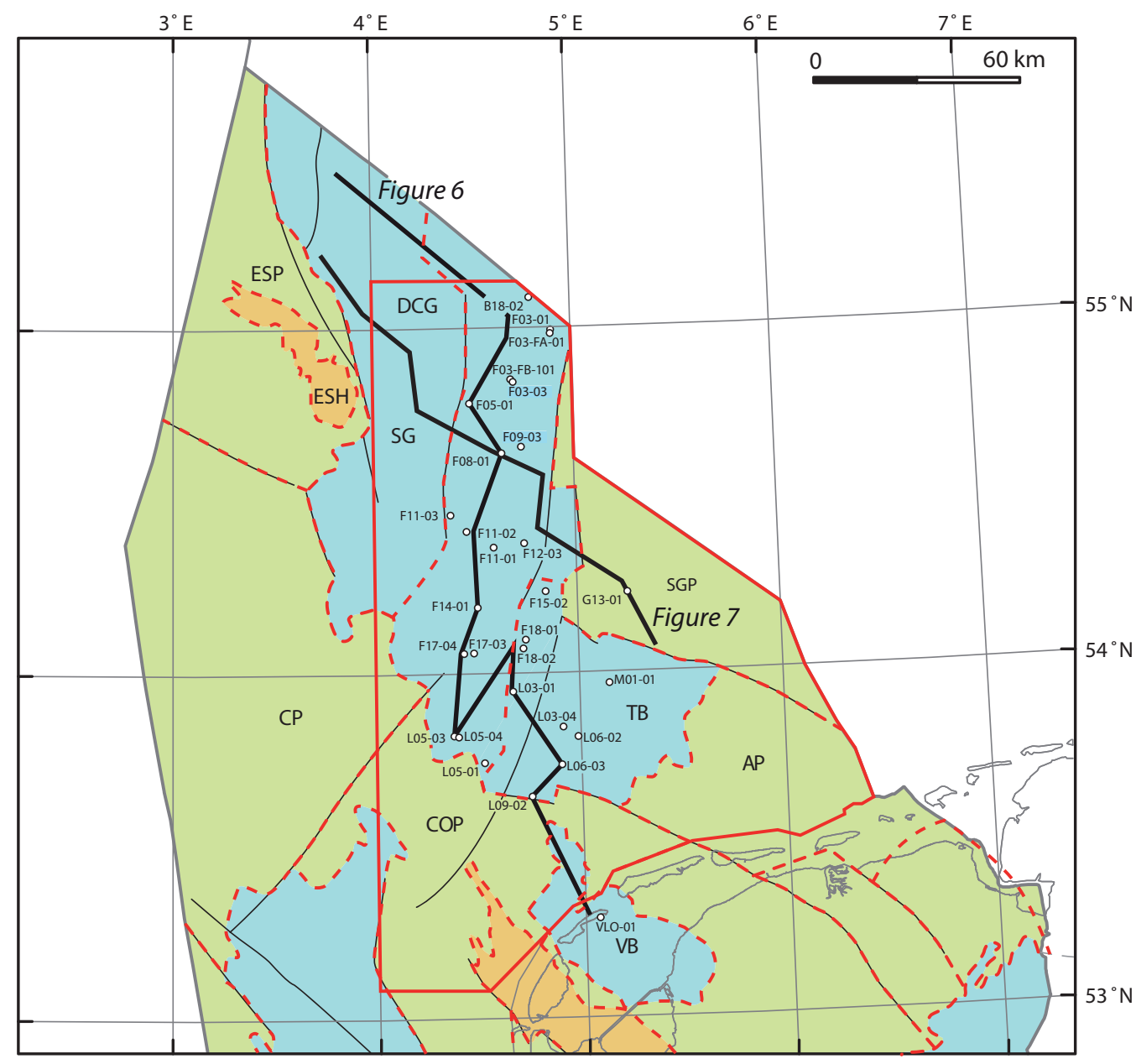

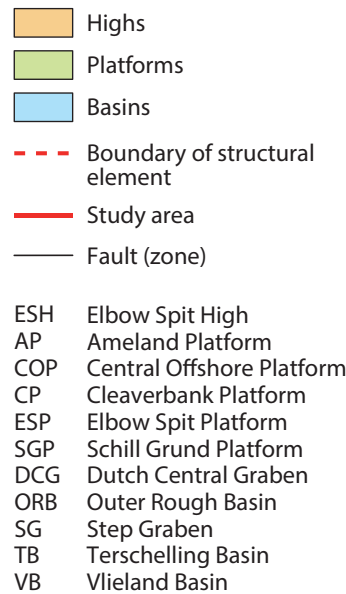

Fig. 4. Map showing the Mesozoic structural elements of the northern part of the Dutch onshore and offshore (based on Kombrink et al., this issue). 
Table 1. Overview showing the changes and adaptations from the existing to the new and revised lithostratigraphy. All revisions are indicated in red.

\begin{tabular}{|c|c|c|c|}
\hline \multicolumn{2}{|c|}{$\begin{array}{c}\text { Current Lithostratigraphy } \\
\text { (Van Adrichem Boogaert \& Kouwe, 1993) }\end{array}$} & \multicolumn{2}{|r|}{ Revised Lithostratigraphy } \\
\hline SL & Schieland Group & SL & Schieland Group \\
\hline SLC & Central G raben Subgroup & SLC & Central Graben Subgroup \\
\hline SLCL & Lower Graben Formation & SLCL & Lower Graben Formation \\
\hline $\begin{array}{l}\text { SLCM } \\
\text { SLCMS }\end{array}$ & $\begin{array}{l}\text { Middle Graben Formation } \\
\text { Middle Graben Sandstone Member }\end{array}$ & $\begin{array}{l}\text { SLCM } \\
\text { SLCMS }\end{array}$ & $\begin{array}{l}\text { Middle Graben Formation } \\
\text { Middle Graben Sandstone Member }\end{array}$ \\
\hline SLCU & Upper Graben Formation & SLCU & Upper Graben Formation \\
\hline SLCP & Puzzle Hole Formation & SLCP & Puzzle Hole Formation \\
\hline SLCF & Friese Front Formation & SLCF (amend.) & Friese Front Formation \\
\hline SLCFR & Rifgronden Member & SLCFR & Rifgronden Member \\
\hline SLCFM & main Friese Front member & SLCFM & main Friese Front member \\
\hline $\begin{array}{l}\text { SLCFO } \\
\text { SLCFT }\end{array}$ & $\begin{array}{l}\text { Oyster Ground Claystone Member } \\
\text { Terschelling Sandstone Member }\end{array}$ & \begin{tabular}{|l|} 
transferred to Scruff Group \\
transferred to Scruff Group**
\end{tabular} & \\
\hline S G & Scruff Group & SG & S cruff Group \\
\hline \multirow[t]{2}{*}{$\begin{array}{l}\text { SGKI } \\
\text { SGKIM }\end{array}$} & $\begin{array}{l}\text { Kimmeridge Clay Formation } \\
\text { main Kimmeridge Clay member }\end{array}$ & SGKI & Kimmeridge Clay Formation \\
\hline & & $\begin{array}{l}\text { SGSK } \\
\text { *SGSKO } \\
\text { **SGSKT } \\
\text { SGSKN } \\
\text { SGSKL }\end{array}$ & $\begin{array}{l}\text { Skylge Formation (new) } \\
\text { Oyster Ground Member (revised name and classification) } \\
\text { Terschelling Sandstone Member (revised classification) } \\
\text { Noordvaarder Member (new) } \\
\text { Lies Member (new) }\end{array}$ \\
\hline SGGS & Scruff Greensand Formation & SGGS (amend.) & Scruff Greensand Formation \\
\hline SGGSB & Scruff Basal Sandstone Member & abandoned & see Skylge Formation \\
\hline SGGSA & Scruff Argillaceous Member & abandoned & see Skylge Formation \\
\hline SGGSP & Scruff Spiculite Member & SGGSP & Scruff Spiculite Member \\
\hline SGGSS & Stortemelk Member & SGGSS & Stortemelk Member \\
\hline & & SGLU & Lutine Formation (new) \\
\hline SGKIC & Clay Deep Member & SGLUC & Clay Deep Member (revised classification) \\
\hline SGKIS & Schill Grund Member & SGLUS & Schill Grund Member (revised classification) \\
\hline
\end{tabular}

\section{Statement of lithostratigraphic problems}

- The inclusion of the lagoonal to restricted marine Oyster Ground Claystone Member and the marginal to shallow marine barrier Terschelling Sandstone Member in the non-marine Friese Front Formation is inconsistent (Fig. 5). The Friese Front Formation is part of the continental Schieland Group (Table 1, Fig. 1).

- There is persistent lithostratigraphic confusion in the Terschelling Basin about where the clayey to sandy intervals below the Scruff Spiculite Member should be placed in the lithostratigraphic framework. Sometimes the clayey to sandy intervals are assigned to the Kimmeridge Clay Formation, sometimes to the Scruff Argillaceous Member (Scruff Greensand Formation) or sometimes to both. Biostratigraphic work revealed that the Scruff Argillaceous Member in the north of the basin gradually changes into clays to the south, posing an additional complication.

- The Kimmeridge Clay Formation in the northern Central Graben exhibits significant differences from the same formation in the Terschelling Basin. The Kimmeridge Clay Formation in the northern Central Graben is older (Late 0xfordian and younger), has a different depositional setting (open marine conditions) and shows organic rich deposition in contrast to the Terschelling Basin. The palaeoenvironment of the Kimmeridge Clay Formation in the Terschelling Basin is shallow marine and is dated as late Late Kimmeridgian and younger.

- Another inconsistency in the Kimmeridge Clay Formation following the Nomenclature of Van Adrichem Boogaert \& Kouwe (1993) is the chronostratigraphical divergence between its Clay Deep and Schill Grund members and the rest of the formation. This is particularly evident in the northern Central Graben (e.g. well B18-02) where the Clay Deep Member is split from the main Kimmeridge Clay by the Scruff Greensand Formation. In this area the Kimmeridge Clay Formation has an age from the Late 0xfordian to Early Portlandian, while the Clay Deep Member is dated as Ryazanian (runctoni-albidum Ammonite zones). In addition the lithology and depositional environment of the Clay Deep Member are different in comparison with the Main Kimmeridge Clay Member (see for details lithostratigraphic description below). In the Terschelling Basin (e.g. well L0602) the same inconsistency is encountered with the shallow marine Schill Grund Member which ranges from the latest Early to Late Ryazanian (kochi-albidum Ammonite zones) in relation to the rest of the older and open marine Kimmeridge Clay Formation in the northern Central Graben.

- In terms of lithology and log character, the predominantly sandy part of the Scruff Argillaceous Member is difficult to 


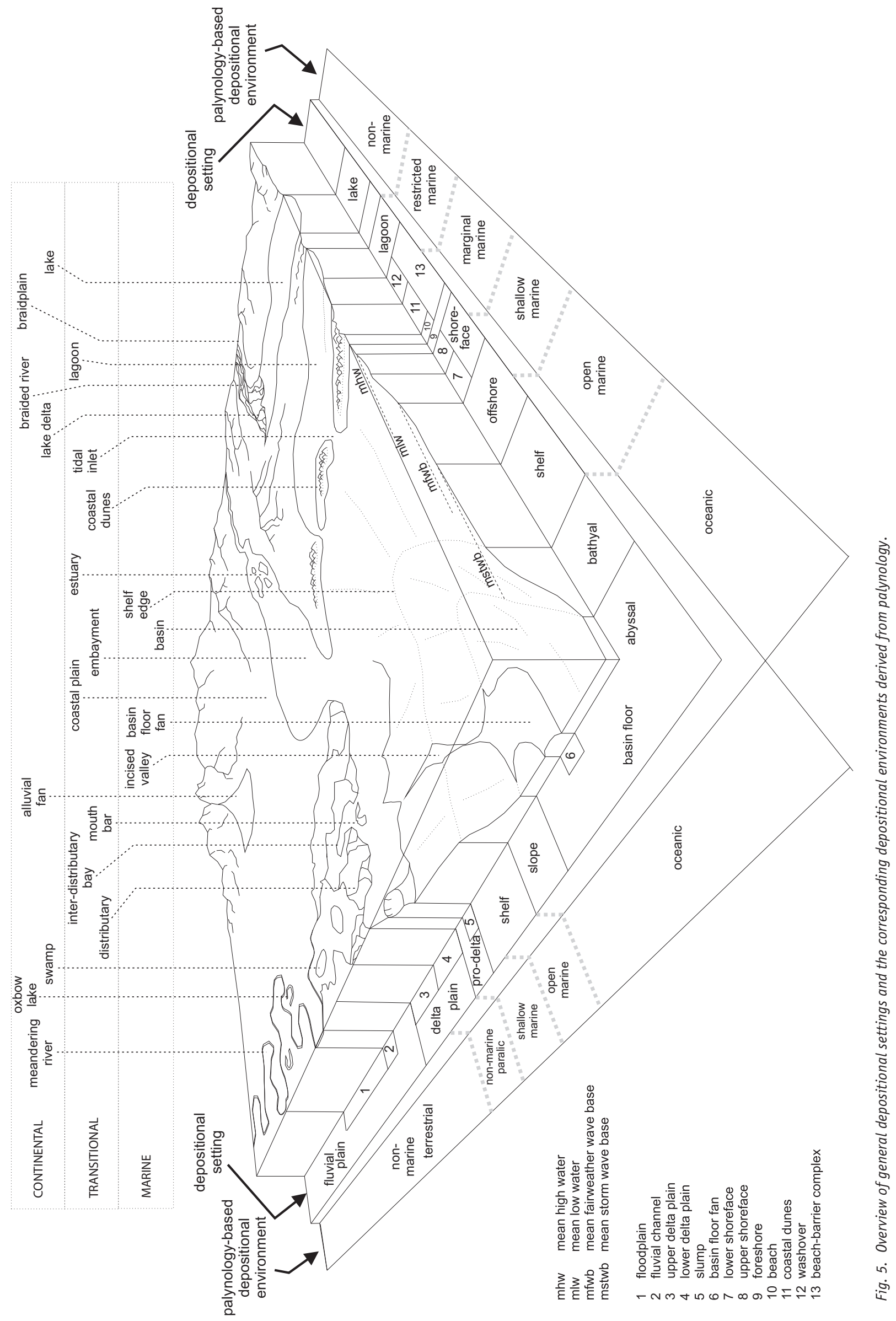

Netherlands Journal of Geosciences — Geologie en Mijnbouw | 91 - 4 | 2012 
distinguish from the underlying Scruff Basal Sandstone Member in the NW part of the Terschelling Basin, Blocks F15, F17, F18 and G16.

- Siliciclastic successions of Sequence 2 sensu Abbink et al. (2006) from the northern Vlieland Basin (situated north of the Wadden Islands and south of the Central Offshore Platform) are either considered to be absent or, when occasionally present, associated with the Lower Zurich Member, Zurich Formation. The Zurich Formation is classified in the mainly continental Schieland Group. Recent studies however show a restricted to shallow marine setting.

\section{Preconditions for lithostratigraphic revision and update}

The stratigraphic framework established by RGD (Geological Survey of the Netherlands) and NOGEPA (Oil \& Gas Exploration \& Production Association of the Netherlands) in the 1993 Nomenclature served as a basis for the present contribution. Basically, the rules for stratigraphic classification defined in the International Stratigraphic Guide (Salvador, 1994) are followed. The strict distinction between lithostratigraphy and chronostratigraphy is maintained, although classification of various facies types without proper lithological markers is occasionally supported by biostratigraphical information and correlation. In some cases new lithostratigraphical names could not be established according to the guidelines of Salvador (1994), because it proved difficult to find appropriate topographic names in the offshore area. Hence nearby onshore topographical names from the Wadden island Terschelling have been used for lithostratigraphical units defined in offshore wells. In one case, to avoid confusion using the same name for a formation and member, the Frysian translation is applied. Furthermore, existing nomenclature is retained as much as possible. New stratigraphic units are defined with proper attention to tectonic setting, depositional environment and age determination.

\section{Lithostratigraphic revision and update}

The aim of this study is to construct a revised scheme for the current inadequate and imperfect lithostratigraphy of the Late Jurassic northern Dutch offshore. The results of the revised and updated nomenclature (Figs 6 and 7) are:

- The establishment of a new formation, the Skylge Formation, comprising all restricted to shallow marine Late Jurassic successions from Sequence 2 sensu Abbink et al. (2006) along the fringes of the Central Graben, Terschelling Basin and northern part of the Vlieland Basin.

- The Skylge Formation will be classified in the Scruff Group. This group encompasses all predominantly marine formations (Van Adrichem Boogaert \& Kouwe, 1993).
- The lagoonal to restricted marine Oyster Ground Claystone Member represents the first transgressive phase in the southern part of the Dutch Central Graben and the Terschelling Basin and will be incorporated in the Skylge Formation (Table 2). It becomes the basal member of the Skylge Formation (Fig. 9). In the Nomenclature of Van Adrichem Boogaert \& Kouwe (1993) the Oyster Ground Claystone Member was part of the non-marine Friese Front Formation.

- The Oyster Ground Claystone Member will be renamed as the Oyster Ground Member (Table 1). The lithological affix has been dropped, since the member does not always entirely consist of claystone. In the southern Terschelling Basin (blocks M4 and M7) and also in parts of the southeastern Central Graben sandstones are interbedded with claystone.

- The new base of the Scruff Group in the Terschelling Basin is lithologically easy to distinguish from the underlying continental to coastal/delta plain deposits of the Friese Front Formation. This can be seen for instance in well L06-02 at depth $2565 \mathrm{~m}$ (Fig. 9). The boundary fits with the transition to the Schieland Group, which is defined by all predominantly continental Late Jurassic and Early Cretaceous successions.

- The marginal to shallow marine Terschelling Sandstone Member will also be transferred to the Skylge Formation of the marine Scruff Group. In the Nomenclature of Van Adrichem Boogaert \& Kouwe (1993), the Terschelling Sandstone Member was also part of the mainly terrestrial Friese Front Formation (Schieland Group). The new classification is obviously more consistent with reference to the depositional setting and sequence.

- The present Scruff Argillaceous Member is replaced by two new members (see below), both accommodated in the Skylge Formation (Fig. 10). The sandy facies in the northwestern part of the Terschelling Basin is classified as the new Noordvaarder Member (well F15-02: interval 3065-3276 m; well F18-02: interval 2182-2440 m). The locally distributed Scruff Basal Sandstone Member was difficult to differentiate from the overlying sandy succession of the Scruff Argillaceous Member and has therefore been incorporated into the Noordvaarder Member (see well F15-02: interval 3246-3276 m, Appendix 1).

- The clayey facies of Sequence 2 sensu Abbink et al. (2006) in the southern part of the Terschelling Basin is attributed to the new Lies Member (well L06-02: interval 2318-2463 m, Figs 6, 9 and 10). Formerly these successions were classified in the Scruff Argillaceous Member (now abandoned) and/or in the Kimmeridge Clay Formation. The Kimmeridge Clay Formation will be amended and restricted to the northern part of the Central Graben, Step Graben and Outer Rough Basin (Figs 6 and 7). Differences in age, depositional setting and lithology justify this limitation. Problems regarding the interfingering of lithologies are now overcome (Fig. 10). 


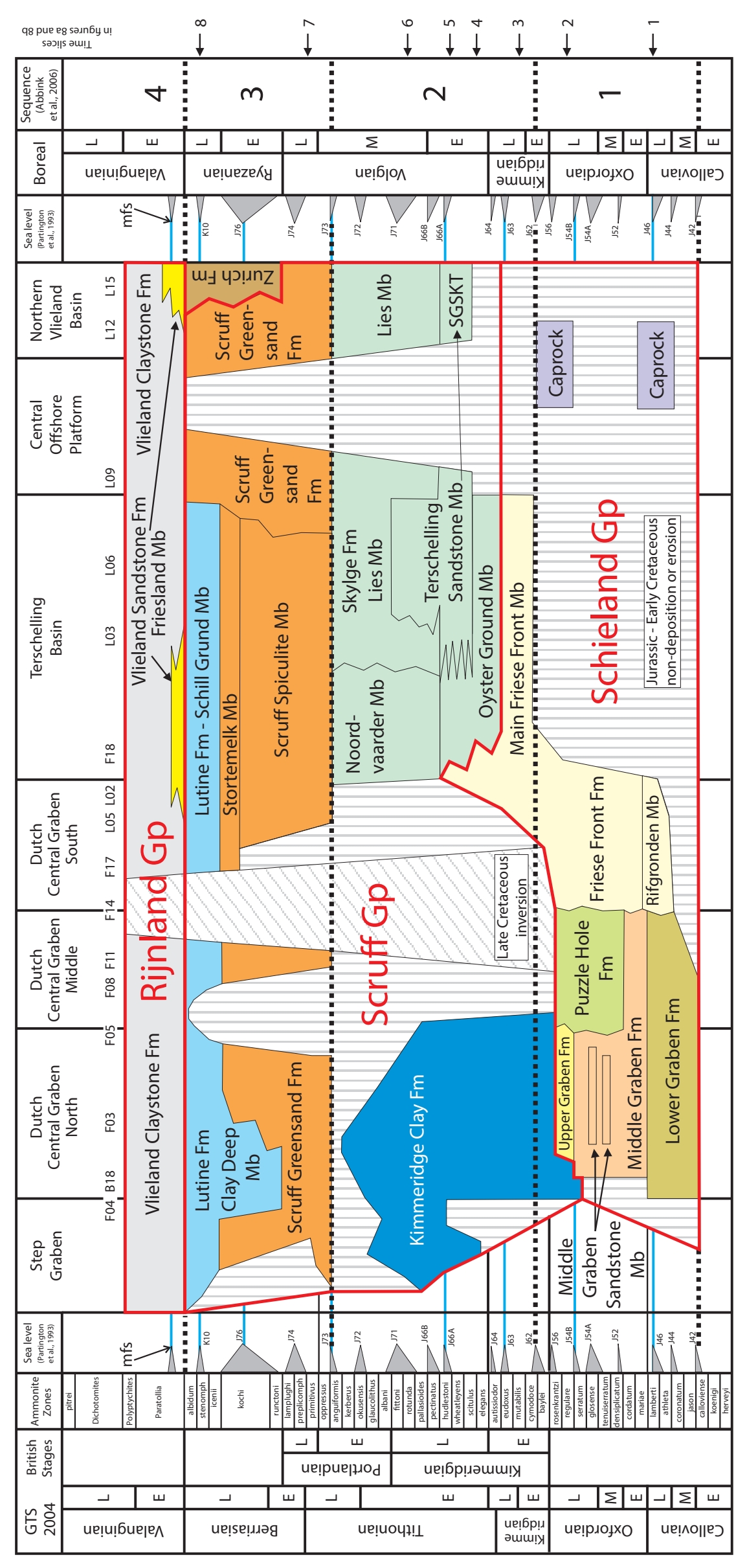

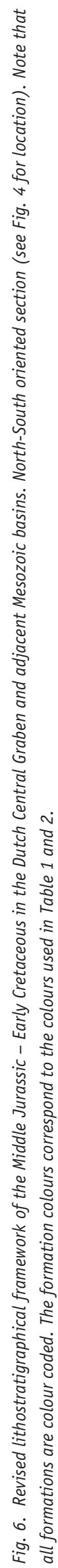




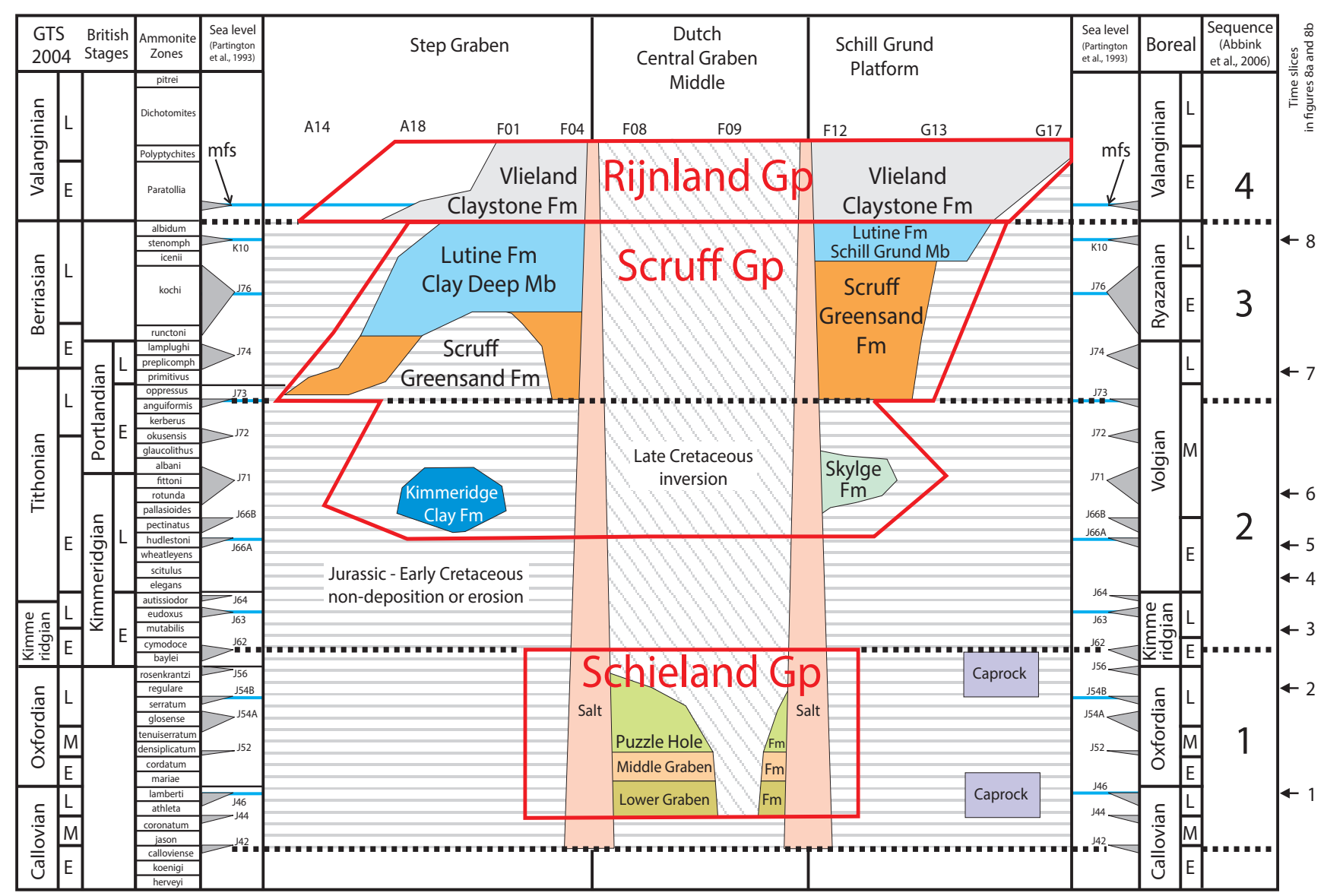

Fig. 7. Revised lithostratigraphical framework of the Middle Jurassic - Early Cretaceous in the Dutch Central Graben and adjacent Mesozoic basins. West-East oriented section (see Fig. 4 for location).

- In the northern Vlieland Basin the clayey facies of Sequence 2 sensu Abbink et al. (2006) may, occasionally, be erroneously associated with the Lower Zurich Member, Zurich Formation (Schieland Group) or with the Scruff Argillaceous Member and/or Kimmeridge Clay Formation. These restricted to shallow marine successions also belong to the new Lies Member (e.g. in well L12-03 \& well L15-03, Fig. 6).

- Based on lithology, seismics and log characteristics, the top of the Skylge Formation can clearly be distinguished from the overlying Scruff Greensand Formation (see, e.g. L06-02: depth $2318 \mathrm{~m}$ along hole, Fig. 9). The transition from the Skylge Formation to the Scruff Greensand Formation coincides with the boundary between Sequence 2 and Sequence 3 sensu Abbink et al. (2006).

- The Scruff Greensand Formation is amended to comprise all shallow marine glauconitic sandstones of the Central Graben, Step Graben, Schill Grund Platform, Terschelling and northern Vlieland basins in Sequence 3 sensu Abbink et al. (2006). Two members are recognised in the Scruff Greensand Formation: the Scruff Spiculite and Stortemelk members (Fig. 6). The Scruff Basal Sandstone and Scruff Argillaceous members are abandoned (Table 1).

- The Clay Deep Member and the Schill Grund Member are part of the Kimmeridge Clay Formation in the Nomenclature of
Van Adrichem Boogaert \& Kouwe (1993; Fig. 1). However, these units are separated from the Kimmeridge Clay Formation by the Scruff Greensand Formation (Fig. 11). In addition, it is mentioned that the main Kimmeridge Clay Member is older (Late 0xfordian-Early Portlandian) than the Clay Deep and Schill Grund members, which are dated as Late Portlandian (post-anguiformis Ammonite Zone) - Ryazanian. Hence both members are given formation status; the Lutine Formation (Figs 6 and 7). As noted, the Kimmeridge Clay Formation is now geographically limited to the northern part of the Dutch Central Graben and adjacent basins.

\section{Lithostratigraphic description and type sections}

In the following section the Late Jurassic and earliest Cretaceous lithostratigraphic units sensu Van Adrichem Boogaert \& Kouwe (1993; Fig. 1) of the northern part of the Dutch offshore are updated and occasionally revised or abandoned. Several units are newly defined and described. The system of codification of lithostratigraphic units used by NAM \& RGD in the 1980 Nomenclature and by RGD \& NOGEPA in the 1993 Nomenclature has been continued in the present publication (Tables 1 and 2). This system shows a three-stage hierarchy with levels of group, formation and member. 
Table 2. Hierarchical subdivision of the new and revised lithostratigraphy of the Rijnland Group (pars.), Scruff Group and the Central Graben Subgroup of the Schieland Group.

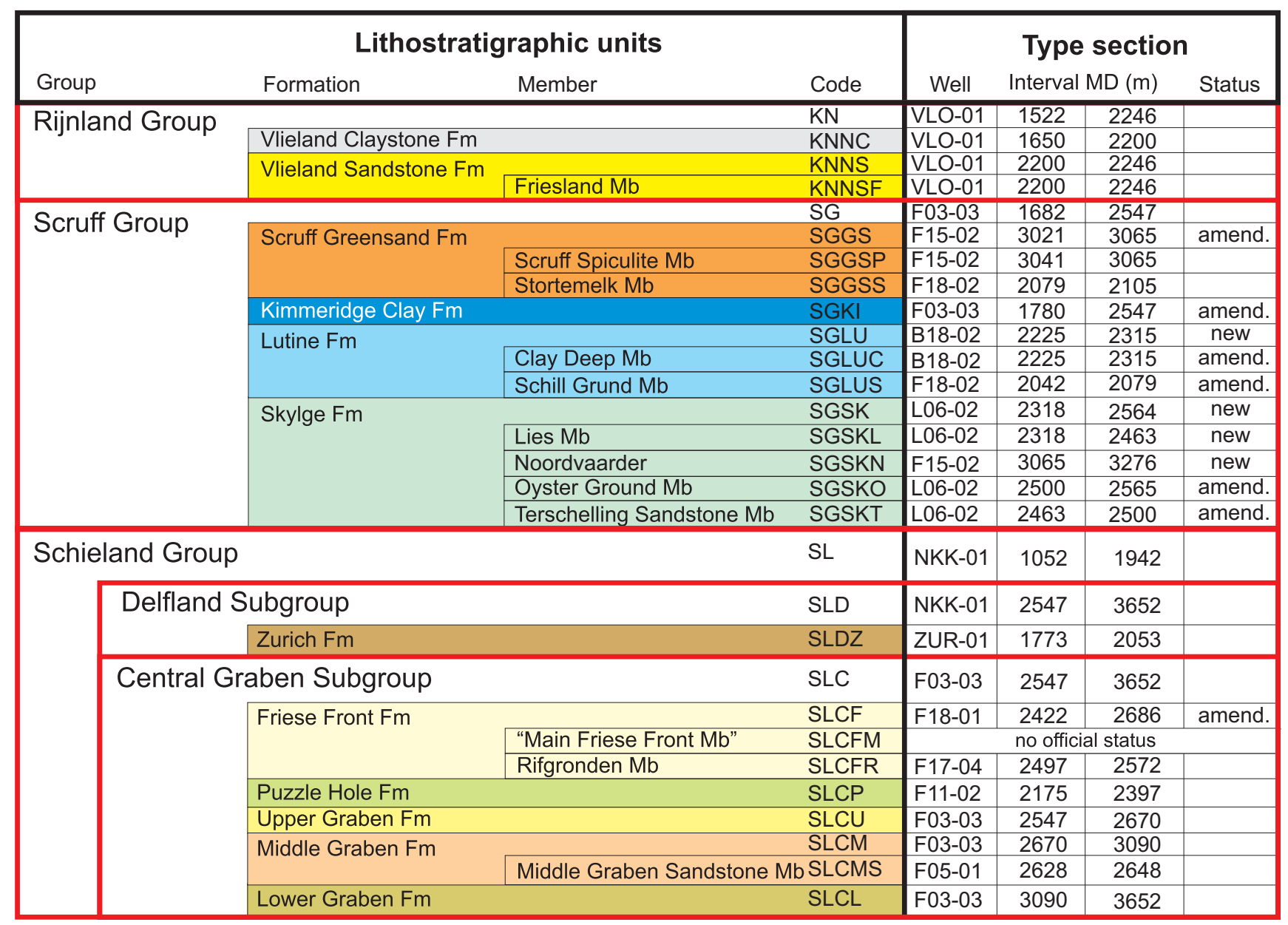

The age interpretation is based on LOD (Last Occurrence Datum) and FOD (First Occurrence Datum) of mainly palynomorphs. Key-references concerning the palynostratigraphy of the Late Jurassic and Early Cretaceous are: Abbink (1998), Abbink et al. (2006), Costa \& Davey (1992), Davey (1979; 1982), Duxbury et al. (1999), Heilmann-Clausen (1987), Herngreen et al. (2000), Partington et al. (1993), Powell (1992) and Riding \& Thomas (1992). The present study is correlated to the standard Boreal Ammonite Zonation. The Late Jurassic sensu anglico, with a 'long' Kimmeridgian stage and Portlandian stage (Cariou \& Hantzperque, 1997) is followed. These stages are calibrated to the standard geologic timescale of Gradstein et al. (2004; Figs 6 and 7).

Remnant Late Jurassic successions, including thick brecciated intervals in sinkholes on top of salt structures, are not included in the lithostratigraphical units but indicated as 'caprock' instead (Figs 6 and 7). The age of the sediment infill of these collapse structures is associated with maximum flooding surfaces (e.g. J46, J56 and/or J66 sensu Partington et al., 1993). The term 'caprock' as here used differs from its usual interpretation. Zechstein caprock refers to unsolvable evaporitic rocks (limestones, anhydrites and Zechstein shales) at the top of (but still inside) salt structures. Zechstein caprock does not include post Zechstein sediments deposited directly on top of the salt structure. Using this definition Late Jurassic/Early Cretaceous clastics in sinkholes are not part of the caprock.

\section{Central Graben Subgroup (SLC)}

The Central Graben was defined as a group by NAM \& RGD (1980) and down-graded in status to a subgroup by Van Adrichem Boogaert \& Kouwe (1993). The subgroup contains all formations of the Schieland Group that have been deposited in the Dutch Central Graben and Terschelling Basin.

\section{Derivatio nominis}

Named after the Dutch Central Graben.

\section{Type section}

Well F03-03 (N 54 $50^{\prime} 45.5$, E 04²4'29.3); interval: 2547-3652 m; thickness: $1105 \mathrm{~m}$ along hole (Van Adrichem Boogaert \& Kouwe, 1993, Annex G-2). 


\section{Additional Reference Section}

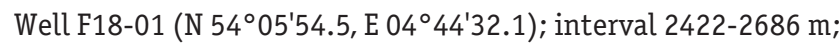
thickness: $264 \mathrm{~m}$ along hole (Van Adrichem Boogaert \& Kouwe, 1993, Annex G-6).

\section{Definition}

Subgroup of mainly non-marine sediments consisting of variegated claystones, silty to clayey sandstones and distinct coal layers or calcareous intercalations are locally present.

\section{Lower boundary}

The Central Graben Subgroup rests unconformable on the marine claystones of the Lower to Middle Jurassic Altena Group, or even on older Lower and Upper Germanic Trias and Zechstein groups.

\section{Upper boundary}

Usually the Central Graben Subgroup is conformably overlain by the marine Scruff Group. In the centre of the Dutch Central Graben however, the Rijnland Group or younger groups unconformably rests on this group, if a prominent Late Kimmerian II unconformity is developed (Table 1 and Fig. 6).

\section{Distribution}

The subgroup is mainly developed in the Dutch Central Graben. In addition to the southernmost Central Graben, the youngest part of the Subgroup, i.e. the late occurrences of the Friese Front Formation, are also present in the Terschelling Basin (Fig. 8a).

\section{Age}

In the Dutch Central Graben the subgroup is dated as Sequence 1 sensu Abbink et al. (2006): Middle Callovian - early Early Kimmeridgian, mutabilis Ammonite Zone (Figs 6 and 7). In the southernmost Central Graben the early Sequence 2 is also reached: late Early - early Late Kimmeridgian, mutabilishudlestoni Ammonite zones. In the Terschelling Basin the age is limited to the earliest Sequence 2: late Early Kimmeridgian, mutabilis-eudoxus Ammonite zones.

\section{Depositional setting}

Mostly non-marine coastal to delta plain deposits, with intermittent marine sediments, deposited during transgressions.

\section{Subdivision}

The Central Graben Subgroup is differentiated into five formations:

Central Graben Subgroup

Lower Graben Formation

Middle Graben Formation

SLCL

SLCM

Upper Graben Formation

SLCU

Puzzle Hole Formation

SLCP

Friese Front Formation
The Friese Front Formation is amended, because in this article the restricted to marginal marine members, i.e. Oyster Ground and Terschelling members, are excluded from this formation and transferred to the predominantly marine Scruff Group, new Skylge Formation.

\section{Lower Graben Formation (SLCL)}

The formation is included in the Schieland Group (SL), into which the former Central Graben Group has been placed as a subgroup (SLC). Originally defined by NAM \& RGD (1980), as Lower Graben Sand Formation. Amended by Herngreen \& Wong (1989), since the formation does not always consist of sandstone alone, the lithological affix has been dropped.

\section{Derivatio nominis}

Named after the Central Graben.

\section{Type section}

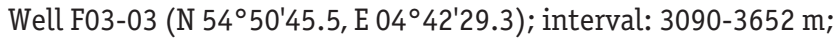
thickness: $562 \mathrm{~m}$ along hole (Van Adrichem Boogaert \& Kouwe, 1993, Annex G-2).

\section{Definition}

Section of greyish brown, very fine to fine-grained, well-sorted sandstones, occurring in beds generally less than $10 \mathrm{~m}$ thick, with intercalations of thin greyish brown silty to sandy claystones. The formation is generally carbonaceous with some distinct coal layers. The individual sandstone bodies have a rather restricted lateral extent. Especially in the upper parts of this unit the GR-log pattern of these beds tends to show a coarsening-upward trend.

\section{Lower boundary}

The base of the formation disconformably overlies Lower-Middle Jurassic formations (Werkendam Formation, the Posidonia Formation, the Aalburg Formation), or formations from the Upper Germanic Triassic Group. Occasionally, the underlying Werkendam Formation may be developed in a coarse-grained oolitic facies, which makes the boundary between the two formations difficult to pick on logs alone.

\section{Upper boundary}

The top of the formation is conformable and formed by the base of the Middle Graben Formation. This boundary is defined at the first distinct coal-bed recognised over most of the studied area.

\section{Distribution}

The formation is restricted to the northern-central parts of the Dutch Central Graben (Fig. 8a1: Blocks F03, F05, F06, F08, F09, F11, F12 and F14) in Sequence 1 sensu Abbink et al. (2006). It shows a wide range in thickness (40-562 $\mathrm{m}$ ), with the thickest 
accumulation in the fault-bounded south-western corner of block F03. In the Danish part of the Central Graben similar strata have also been recognised and are referred to as the Lulu Formation (Koch, 1983; Herngreen \& Wong, 1989; Michelsen \& Wong, 1991; Michelsen et al., 2003).

\section{Age}

Sequence 1 sensu Abbink et al. (2006): Middle-Late Callovian. Significant dinoflagellate species, from which this interpretation is derived, are: Liesbergia scarburghensis (First Occurrence Datum, 'FOD': M. Callovian), Ctenidodinium spp. (a.o. C. continuum, C. gochtii-kettonense group, C. sellwoodii-stauromatos group), Energlynia acollaris, Lithodinia jurassica (Last 0ccurrence Datum, 'LOD': Callovian), Meiourogonyaulax borealis, Pareodinia prolongata (LOD: Callovian), Rigaudella aemula, Scriniodinium galeritum, Stephanelytron spp., Systematophora spp., Wanaea fimbriata, and W. thysanota (FOD: M. Callovian). There is a consistent presence of a characteristic sporomorph association with Precicatricosisporites spp. (F0D: M. Callovian). The ostracods Lophocythere interrupta interrupta, L. bipartita, Fuhrbergiella horrida horrida, Pseudohutsonia tuberosa and Lophocythere interrupta are rare, but characteristic elements in this formation (e.g. wells F17-03 and F14-01).

\section{Palynofacies}

In the lower part of the formation marine influence is absent. Sporomorphs dominate the associations. Most abundant are in particular simple psilatrilete spores, with Classopollis, Perinopollenites, Cerebropollenites and bisaccates. The psilatrilete spores (various fern families) refer to the Fluvial Ecogroup (Abbink, 1998). In the upper part the relative abundances of the sporomorph eco-groups generally change and show a near coastal setting, with occasional marine incursions, consistent with the inferred J46 MFS sensu Partington et al. (1993) from the lamberti Ammonite Zone.

\section{Depositional Setting}

Fluvial to delta- and coastal plain.

\section{Middle Graben Formation (SLCM)}

The formation has been included in the Schieland Group (SL). Original definition by NAM \& RGD (1980), as Middle Graben Shale Formation, but renamed and re-described as Middle Graben Formation by Van Adrichem Boogaert \& Kouwe (1993). The type section of the 'Lower Kimmeridge Clay Member' of NAM \& RGD (1980) has been transferred to this formation by Herngreen \& Wong (1989).

\section{Derivatio nominis}

Named after the Central Graben.

\section{Type section}

Well F03-03 (N 54 50'45.5, E 04²42'29.3); interval 2670-3090 m; thickness $420 \mathrm{~m}$ along hole (Van Adrichem Boogaert \& Kouwe, 1993, Annex G-2).

\section{Definition}

Section of grey, locally very silty, carbonaceous claystones. In the northern part of the F-quadrant (e.g. F02, F03 and F05) one thick or locally two sandstone beds may be intercalated (Middle Graben Sandstone Member, SLCMS). At the base of the formation three thin but distinct coal seams occur. They are laterally very extensive and form important lithostratigraphic markers.

\section{Lower boundary}

The lower boundary with the Lower Graben Formation is placed below the base of the lowermost distinct coal seam, immediately overlying thick sand beds (well F03-03 at $3090 \mathrm{~m}$ in Van Adrichem Boogaert \& Kouwe, 1993, Annex G-2).

\section{Upper boundary}

The upper boundary of the formation is the conformable contact with the marine fines of the Kimmeridge Clay Formation (northern part of the F02 and F03 blocks) or barrier sands of the Upper Graben Formation (in the lower half of the F02 \& F03 blocks and the greater part of the F05 and F06 blocks) in the northern part of the Dutch Central Graben. To the south it is overlain by the coal-bed dominated Puzzle Hole Formation (Figs 6 and 7, southernmost part of F05, F06 and in the F08, F11 and F14 blocks). The transition from the Middle Graben Formation to the Puzzle Hole Formation is gradual. Therefore, the upper part of the formation in e.g. F08 is equivalent to the basal Puzzle Hole Formation in F14. The basal coal beds with intercalated marine clays can be correlated with the lowermost Rifgronden Member of the Friese Front Formation (southern Dutch Central Graben).

\section{Distribution}

The distribution area is somewhat smaller than the Lower Graben Formation: in the northern and central parts of the Dutch Central Graben, Blocks B18, F3-F14.

\section{Age}

Sequence 1 sensu Abbink et al. (2006): Early-Middle 0xfordian. Diagnostic dinoflagellates are: Liesbergia scarburghensis (LOD: M. Oxfordian), Leptodinium subtile (FOD: E. Oxfordian), Polystephanephorus paracalathus (LOD: E. Oxfordian), Scriniodinium crystallinum, Systematophora fasciculigera/penicillata (FOD: E. Oxfordian), S. valensii, S. spp., Wanaea fimbriata (LOD: E. Oxfordian), W. thysanota (LOD: E. Oxfordian). Among the sporomorphs the frequent presence of the Precicatricosisporites spp. complex can be noted and the top occurrence of Neoraistrickia gristhorpensis (LOD: E. Oxfordian). The formation is characterised by a typical ostracod assemblage consisting of 
Time slice 1

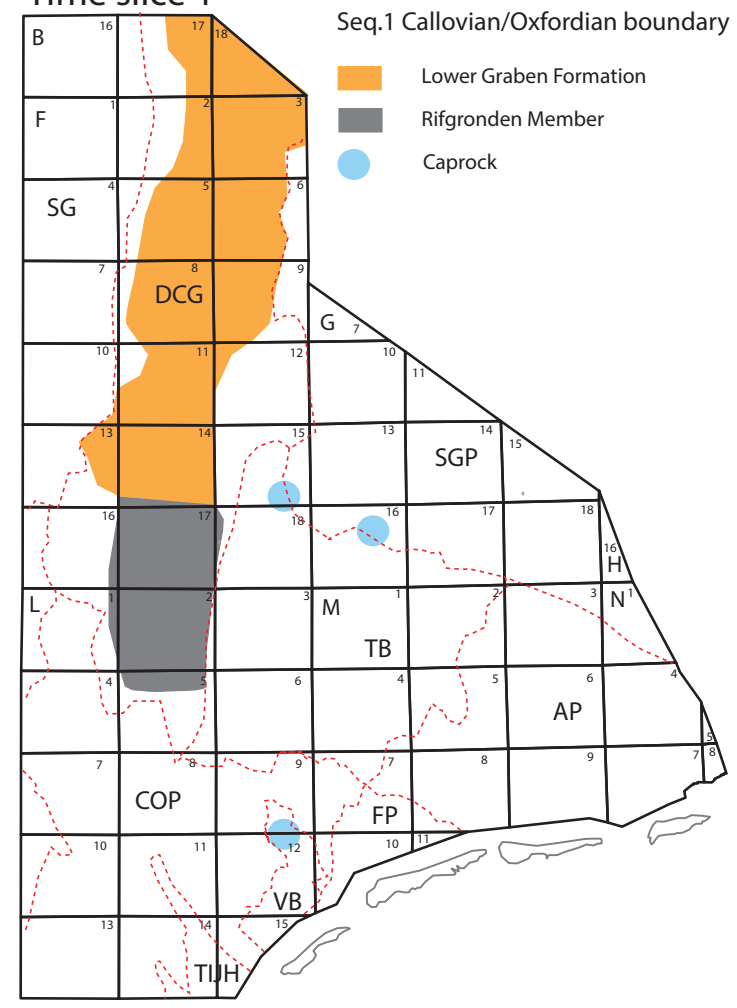

Time slice 3

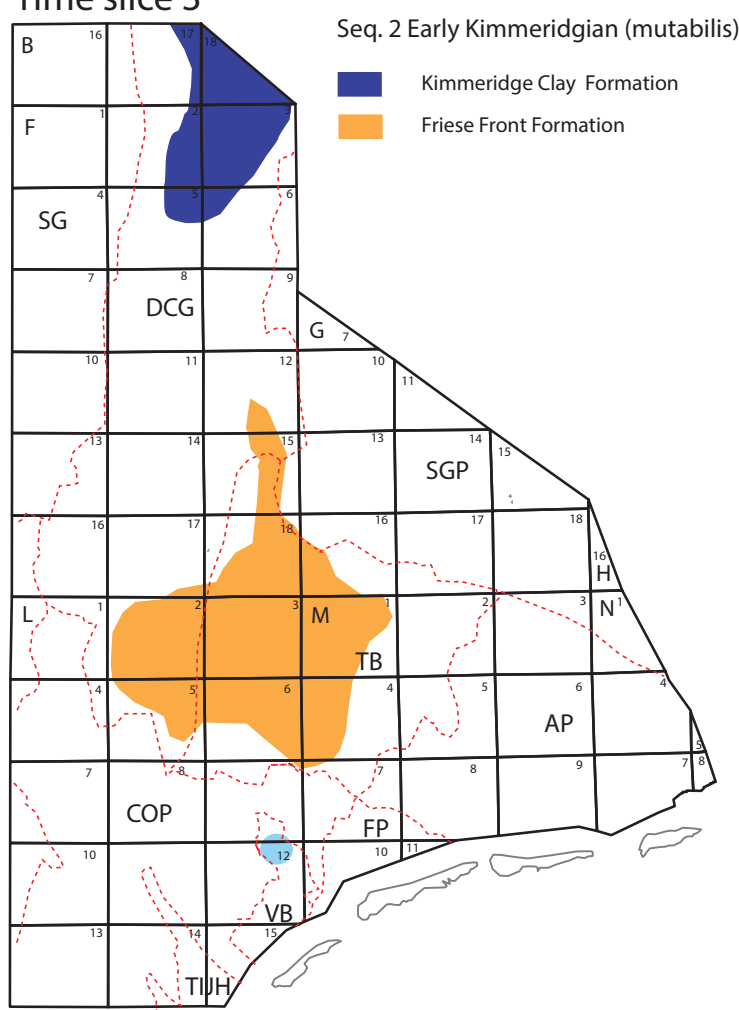

Time slice 2

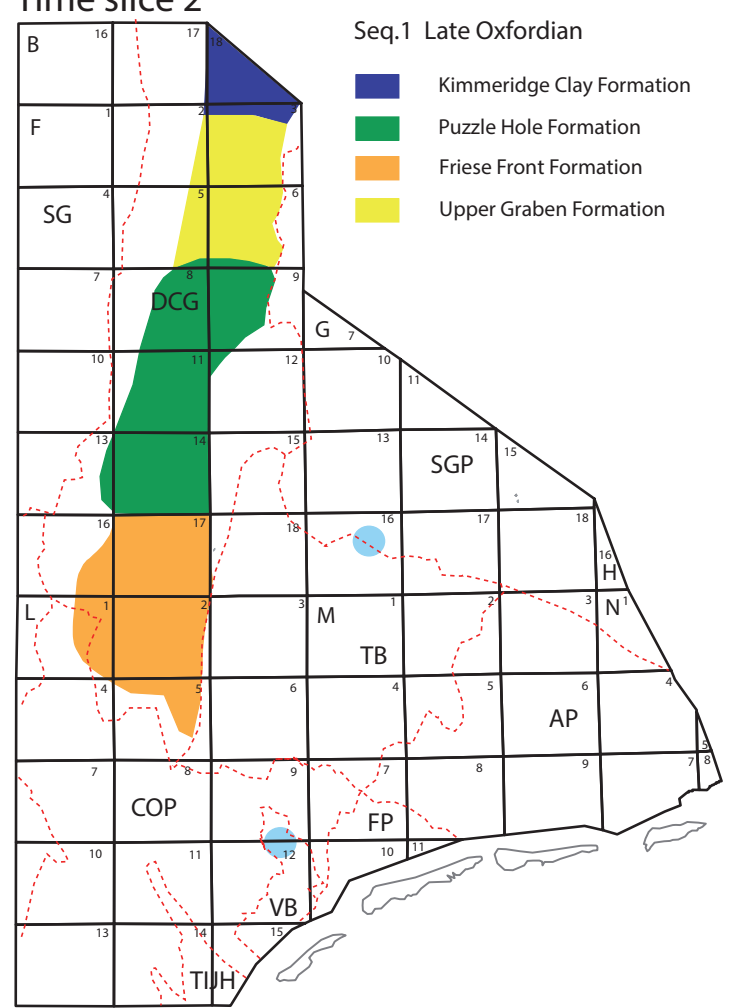

Time slice 4

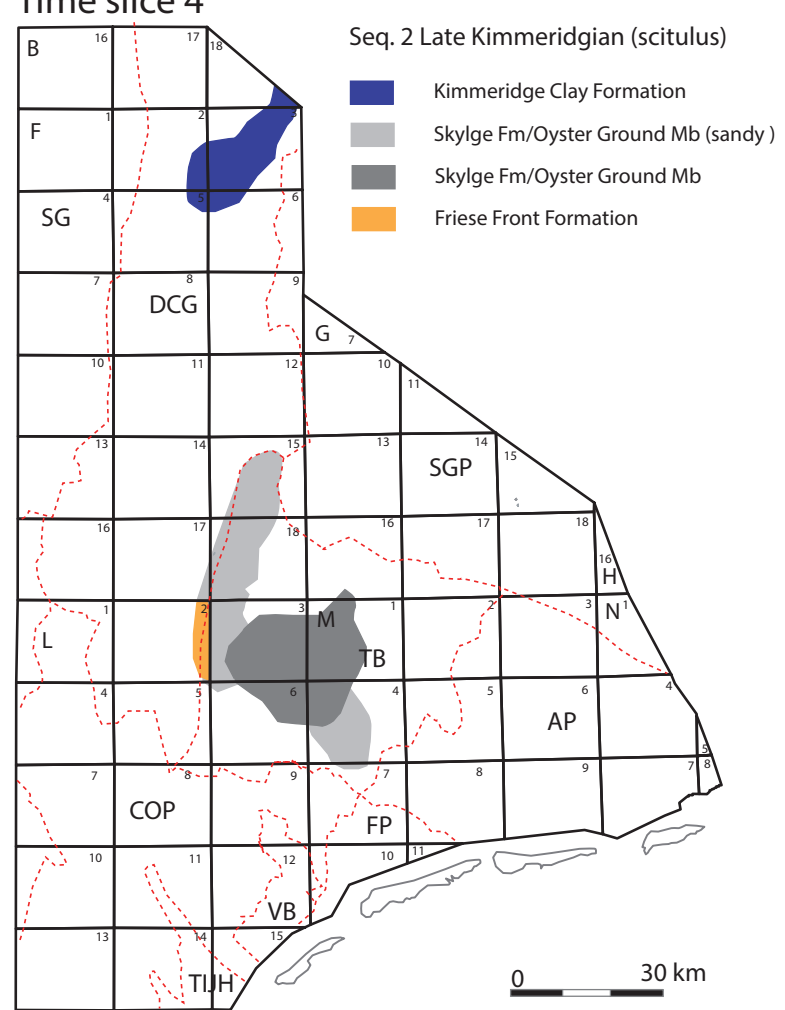

Fig. $8 a$.

Figs $8 a$ and $8 b$. Schematic Late Jurassic - Early Cretaceous time slices showing the facies distribution in the study area through time. Chronostratigraphic reference is sensu Anglico (British Stages). Note that no distinction has been made in the uncoloured areas between non-deposition and erosion. 
Time slice 5

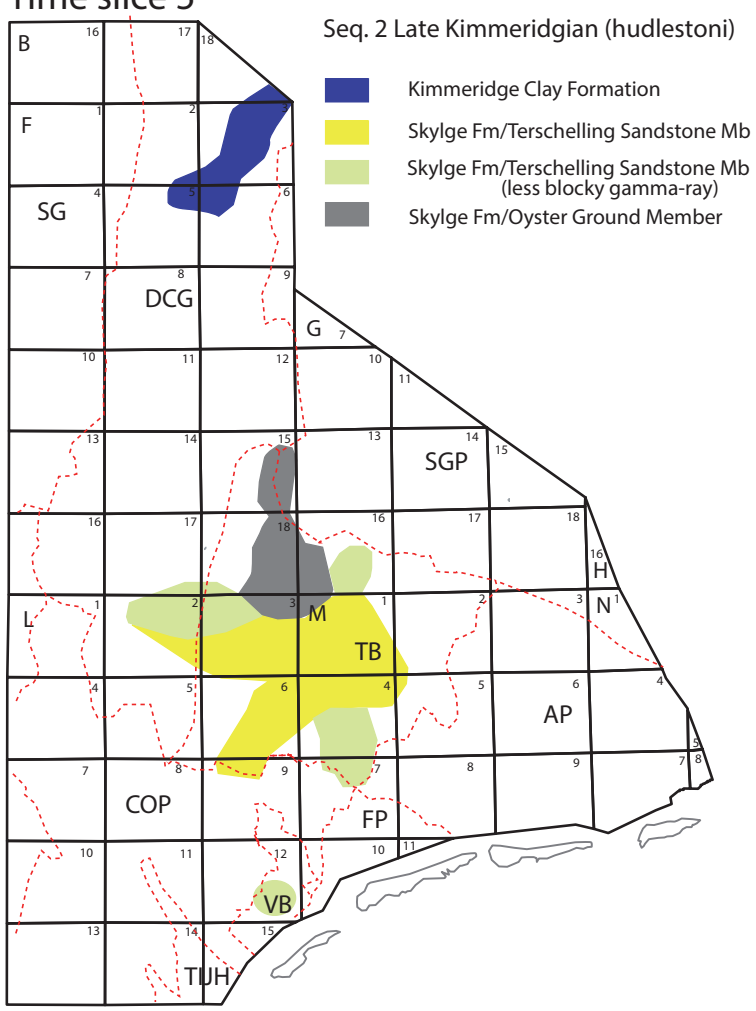

Time slice 7

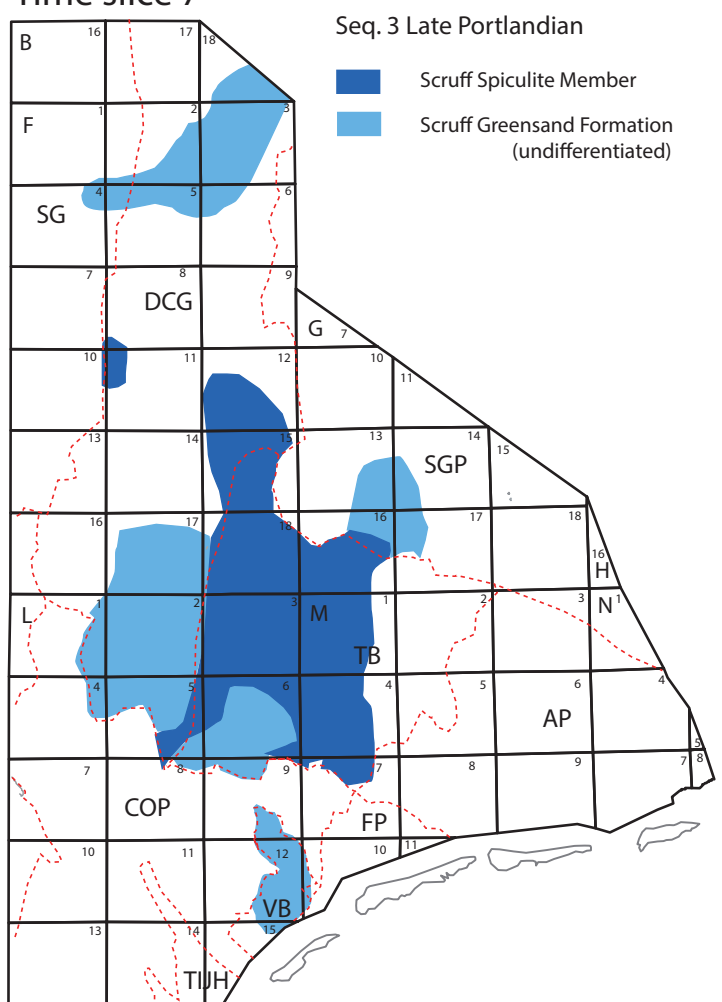

Time slice 6

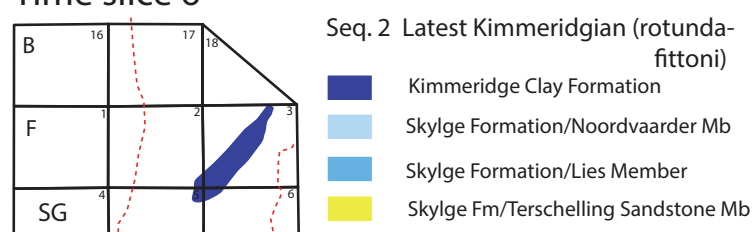

open marine

semi-enclosed shallow marine

shallow marine

restricted-shallow marine

Fig. $8 b$. barrier system

barrier system (less sandy)

lagoonal

lagoonal (sandy)

\section{Time slice 8}

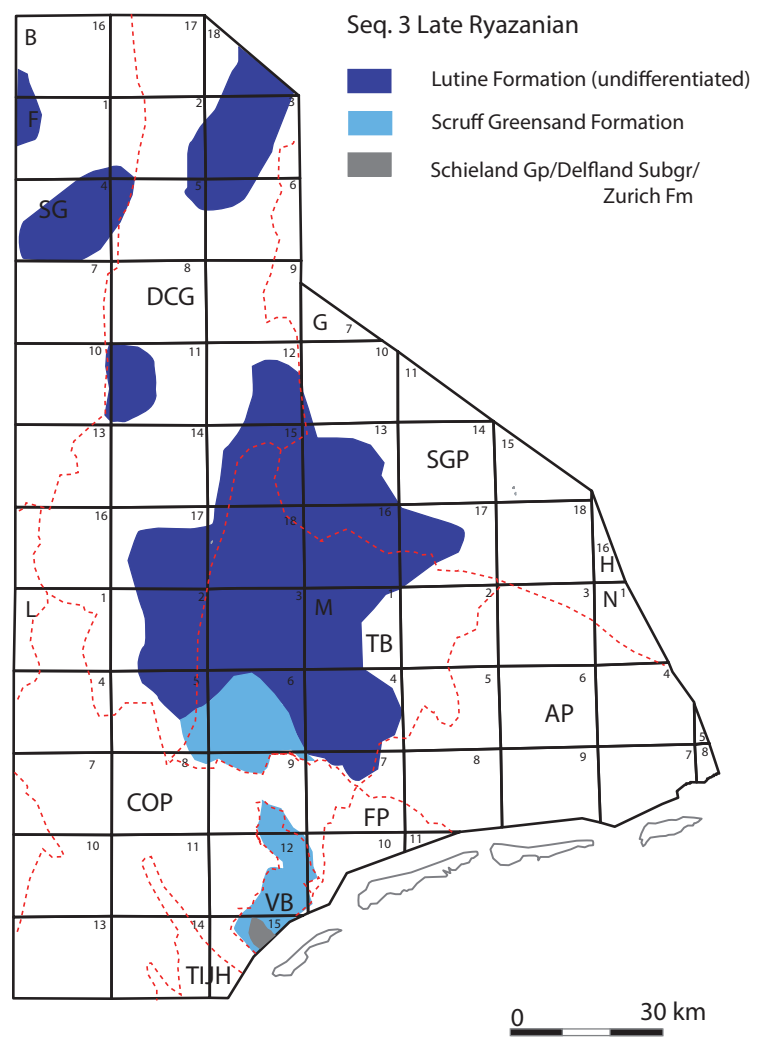

$0 \quad 30 \mathrm{~km}$

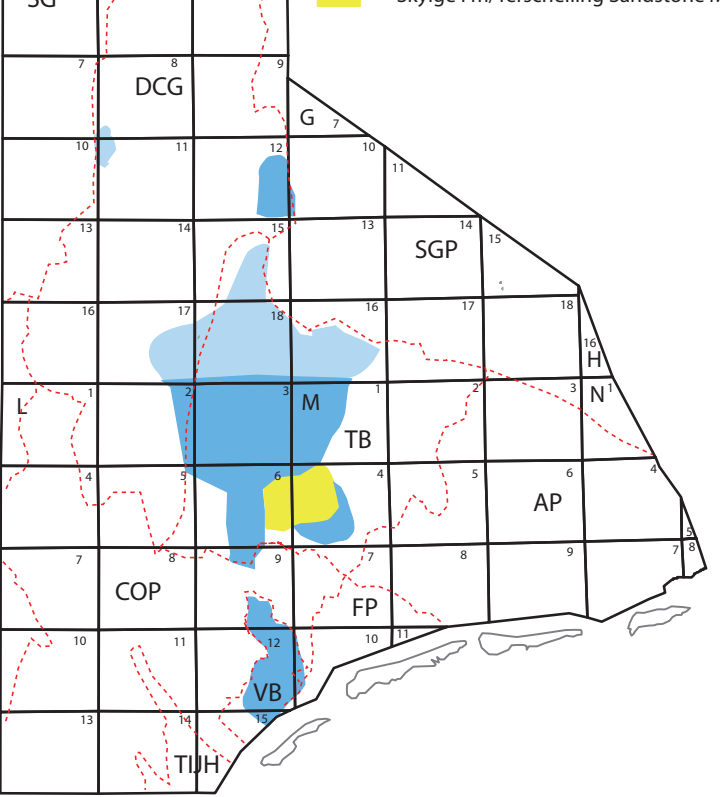




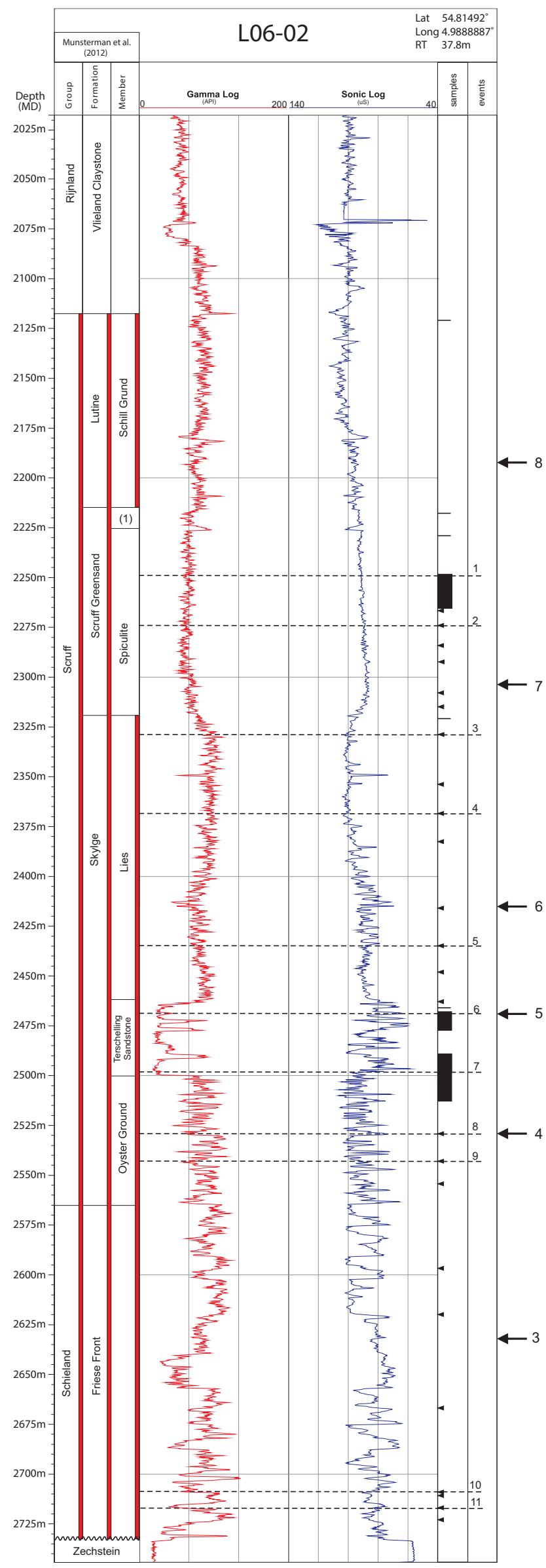

a number of yet undescribed species of Galliaecytheridea (see Herngreen \& Wong, 1989). The Middle Graben Formation is age equivalent to the Oisterwijk Limestone Member and part of the Upper Brabant Marl Member of the Brabant Formation (Altena Group) in the Roer Valley Graben.

\section{Palynofacies}

Distinct marine indications are found only in the claystones alternating with the coal beds at the base of the formation. The basal coal beds were formed in extensive coastal-swamps. Higher up in this unit only terrestrial palynomorph assemblages were encountered with occasionally a weak marine influence (e.g. J52 MFS sensu Partington et al., 1993). The palynomorphs indicate a lacustrine to temporarily lagoonal setting (fresh to brackish water algae Botryococcus dominate). A climate shift (warmer/ drier conditions) is shown in the Coastal/Lowland Sporomorph Ecogroup ratio in the Middle 0xfordian, densiplicatum Ammonite Zone.

\section{Depositional setting}

Lacustrine to marginal marine embayment.

Middle Graben Sandstone Member (SLCMS)

The Middle Graben Sandstone Member, defined by Herngreen \& Wong (1989), is part of the Middle Graben Formation (Fig. 6).

\section{Derivatio nominis}

Named after the Central Graben.

\section{Type section}

Well F05-01 (N 54ํㄱ'10.7, E 04²29'14.6); interval 2628-2648 m; thickness $20 \mathrm{~m}$ along hole (Van Adrichem Boogaert \& Kouwe, 1993, Annex G-3).

\section{Definition}

Sections of yellow fine-medium, moderately sorted sandstone with calcareous cement. The sands are often characterised by one or two coal beds, showing a spiky character on the GR-log.

Updated lithostratigraphic units

(1) Stortemelk

- cuttings sample

- side-wall core sample

core

$\longleftarrow$ Time slices in figures $8 \mathrm{a}$ and $8 \mathrm{~b}$

Palynological events

1 Top abundant Classopollis echinat

2 Top Dingodinium tuberosum

3 Top Glossodinium dimorphum

4 Base Gochteodina villosa

5 Top Rhynchodiniopsis martonense

6 Top common Dichadogonyaulax pannea

7 Top Kraeuselisporites tubbergensis

8 Base Gochteodinia mutabilis

9 Base abundant Classopollis echinata

10 Top Retitriletes undulatus

11 Base Cicatricosisporites spp.

Fig. 9. Well L06-02: type section for the Skylge Formation. 
The sandy bodies have a distinct coarsening upward trend. In a few areas (F03-FB Field) a double sand body is present, both parts with a coarsening upward trend.

\section{Boundaries}

Top and base of this member are characterised by distinct (Gamma Ray, Int. transit time \& Resistivity) log breaks defining the contacts with the under- and overlying non-calcareous claystones of the Middle Graben Formation.

\section{Distribution}

Restricted to the northern Dutch Central Graben, Blocks F02, F03, F05 and F06.

\section{Age}

Sequence 1 sensu Abbink et al. (2006): Early-Middle 0xfordian. Characteristic palynomorphs are Contignisporites type 13/28 (FOD: M. Oxfordian), Striatella spp., Precicatricosisporites inae, $P$. irregularis and Neoraistrickia gristhorpensis (LOD: E. Oxfordian).

\section{Palynofacies}

Terrestrial palynomorphs, like bisaccates, psilatrilete spores, Perinopollenites and Cerebropollenites are abundant. The fresh to brackish water algae Botryococcus is fairly common. A minor marine component may be present, like e.g. Dichadogonyaulax sellwoodii. The palynomorphs suggest a lacustrine depositional environment with occasionally marginal marine influence.

\section{Depositional setting}

Local prograding lake delta fill complexes.

\section{Upper Graben Formation (SLCU)}

The formation is included in the Schieland Group. The formation was defined by NAM \& RGD in 1980 and amended by Herngreen \& Wong (1989) and by Van Adrichem Boogaert \& Kouwe (1993).

\section{Derivatio nominis}

Named after the Central Graben.

\section{Type section}

Well F03-03 (N 54 50'45.5, E 04²42'29.3); interval: 2547-2670 m; thickness: $123 \mathrm{~m}$ along hole (Van Adrichem Boogaert \& Kouwe, 1993, Annex G-2).

\section{Definition}

The formation consists of two units of greyish brown, finegrained, carbonaceous sandstones, separated by a silty clay succession. Both sand intervals, but especially the upper sand bed, tend to display a funnel-shaped GR-log pattern.

\section{Lower boundary}

The formation is conformably underlain by the Middle Graben Formation.

\section{Upper boundary}

The top is conformably overlain by the marine claystones of the Kimmeridge Clay Formation. To the north it pinches out into the Kimmeridge Clay Formation (Fig. 6). To the south, the formation grades into the paralic Puzzle Hole Formation at the southern margin of blocks F05-F08 (Herngreen \& Wong, 1989).

\section{Distribution}

The Upper Graben Formation is developed in the northern Dutch Central Graben in blocks F02, F03 and the northern part of F05 and F06 (Fig. 8a2). The general depositional trend is N-S directed.

\section{Age}

Sequence 1 sensu Abbink et al. (2006): Late 0xfordian. Diagnostic dinoflagellate forms are Ellipsoidictyum sp., Glossodinium dimorphum (FOD: M. Oxfordian) and Leptodinium arcuatum (FOD: M. Oxfordian). The top occurrence of Systematophora valensii has been recorded in this formation. Among the sporomorphs the earliest representatives of the ConcavissimisporitesImpardecispora complex (FOD: Late 0xfordian) can be noted and also Varirugosisporites granituberosus (FOD: Late 0xfordian). The few ostracods found in this formation show more resemblance to assemblages from the underlying Middle Graben Formation than to those of the overlying marine sediments of the Kimmeridge Clay Formation. Three, probably endemic, species of Galliaecytheridea characterise this formation.

\section{Palynofacies}

Compared to the underlying Middle Graben Shale, the sporomorph variety decreases. Psilatriletes (including Gleicheniidites), Eucommiidites, Perinopollenites, inaperturates and bisaccates dominate the sporomorph category. Locally Densoisporites and Callialasporites may be significant. Marine dinoflagellate cysts occur in rare to fair numbers. Fairly coarse, black blocky palynodebris and opaque clasts are very common, indicating barrier island and storm deposits. The Upper Graben barrier system separates the paralic Puzzle Hole Formation to the south from the marine Kimmeridge Clay realm in the north. The Late Oxfordian J54 MFS sensu Partington et al. (1993) forms the base Kimmeridge Clay Fm. in the F9/F6/F3 blocks.

\section{Depositional setting}

Marginal marine barrier-island system.

\section{Puzzle Hole Formation (SLCP)}

The formation is included in the Schieland Group. It was defined by NAM and RGD in 1980 and amended by Herngreen \& Wong (1989) and by Van Adrichem Boogaert \& Kouwe (1993). NAM \& 


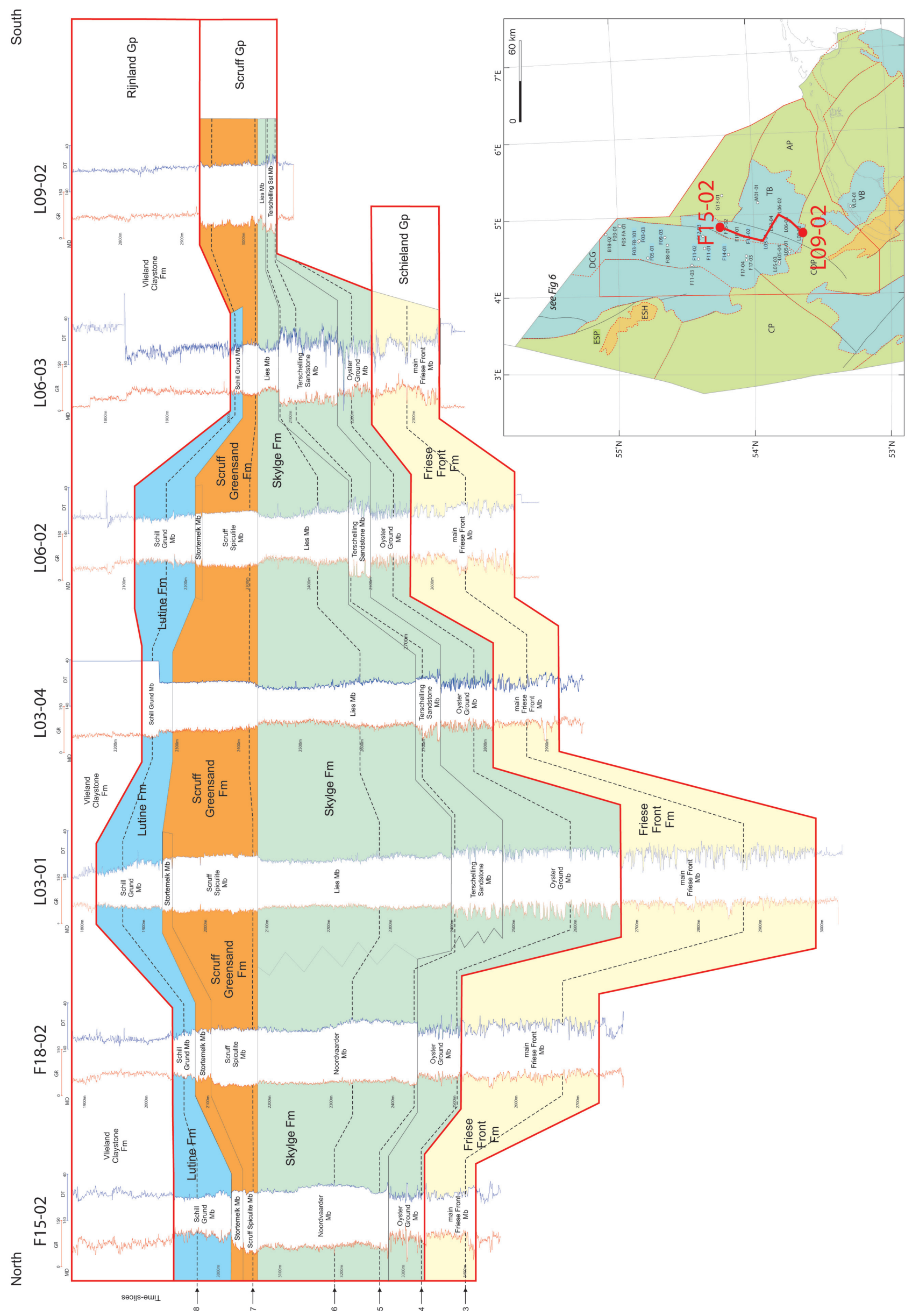

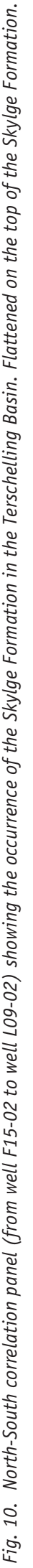


RGD (1980) considered their Puzzle Hole Formation to be a siltysandy tongue within the Kimmeridge Clay Formation, and part of the Scruff Group. Because of its predominantly terrestrialparalic character, Herngreen \& Wong (1989) attributed the Puzzle Hole Formation to the Central Graben Group. In Van Adrichem Boogaert \& Kouwe (1993) it is transferred in the new Schieland Group, into which the Central Graben Group has been amended as a subgroup. The top of the type section has been shifted in order to transfer the atypical, marine interval 2175$2149 \mathrm{~m}$ to the Kimmeridge Clay Formation. This is supported by log patterns and palynology. The Puzzle Hole Formation can be differentiated from other formations in the Central Graben Subgroup by its large number of intercalated coal seams. The other formations contain at most only a few coal seams.

\section{Derivatio nominis}

Named after the Puzzle Hole Bank in the Dutch northern offshore region.

\section{Type section}

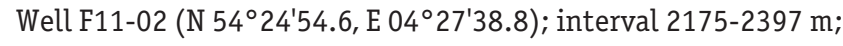
$222 \mathrm{~m}$ along hole (Van Adrichem Boogaert \& Kouwe, 1993, Annex G-4).

\section{Definition}

The formation consists of light brownish-grey carbonaceous claystones with intercalations of siltstones and thin sandstones. Coal seams are frequent (10 to 20 seams per $100 \mathrm{~m}$ interval) and give the formation the typical seismic response. The sandstones, in particular to the south, show a fining-upward character. The Puzzle Hole Formation displays a typical serrate pattern on both gamma-ray and sonic logs as a result of the rapid alternation of thin sandstones, siltstones, clay- stones and coal seams.

\section{Lower boundary}

The formation conformably overlies the Middle Graben Formation. The upper Middle Graben Formation is characterised by a very low sand/claystone ratio and an absence of coal beds.

\section{Upper boundary}

In most wells the Puzzle Hole Formation is overlain unconformably by sediments of the Rijnland Group or younger groups as a result of Sub-Hercynian/Laramide inversion erosion. In the type section (Van Adrichem Boogaert \& Kouwe, 1993, Annex G-4), however, the marine claystones of the Kimmeridge Clay Formation conformably overlie the Puzzle Hole Formation. The Puzzle Hole Formation occupies an intermediate position between the Friese Front Formation to the south and the Upper Graben Formation and Kimmeridge Clay Formation to the north. The transition to the Friese Front Formation is a fault-associated boundary through the F15-F17 blocks.

\section{Distribution}

The Puzzle Hole is deposited in the central part of the Dutch Central Graben, the southern parts of blocks F05 and F06 and blocks F08, F09, F11, F12 and F14 (Fig. 8a2).

\section{Age}

Sequence 1 sensu Abbink et al. (2006): Middle 0xfordian to early Early Kimmeridgian. In occasional marine incursions characteristic dinoflagellate associations comprise Dichadogonyaulax chondrum (LOD: E. Kimmeridgian, cymodoce Ammonite Zone), Gonyaulacysta jurassica (abundant; LCOD: E. Kimmeridgian, cymodoce Ammonite Zone), Hystrichosphaerina orbifera, Occisucysta monoheuriska and Systematophora. Among the sporomorphs Trilites minutus, Precicatricosisporites complex (LOD: early Early Kimmeridgian, mutabilis Ammonite Zone), Retitriletes undulates (LOD: early Early Kimmeridgian, mutabilis Ammonite Zone) and Striatella reticulata occur. Eripleura eleanorae and Galliaecytheridea punctata are important ostracods.

\section{Palynofacies}

In contrast to the claystones in between the coal beds near the base of the Middle Graben Formation, which are marine, those throughout the Puzzle Hole Formation are distinctly continental. The samples show predominately terrestrial sporomorph associations, dominated by psilatrilete spores, bisaccate pollen grains and Perinopollenites. Abundant plant debris is found. Occasionally some marine influence is recorded.

\section{Depositional setting}

Lower delta plain; lagoonal tidal flats, estuary and tidal channels, bay head deltas and mouthbars.

\section{Friese Front Formation (SLCF), amended}

The formation is included in the Schieland Group (Table 1). The formation has been defined and described by Van Adrichem Boogaert \& Kouwe (1993). The definition is modified here: the restricted to shallow marine 0yster Ground Claystone and Terschelling members are transferred from the Friese Front to the new Skylge Formation (Scruff Group). One formal member is recognised in the Friese Front Formation: Rifgronden Member (Fig. 6). Strata between the Rifgronden and Oyster Ground members are assigned to the undifferentiated Friese Front Formation (Fig. 6) and indicated informally as 'main Friese Front member' in Van Adrichem Boogaert \& Kouwe (1993).

\section{Derivatio nominis}

Named after the Friese Front, a fisherman's name for the shelf break area north of the Wadden Islands, near the type locality. 


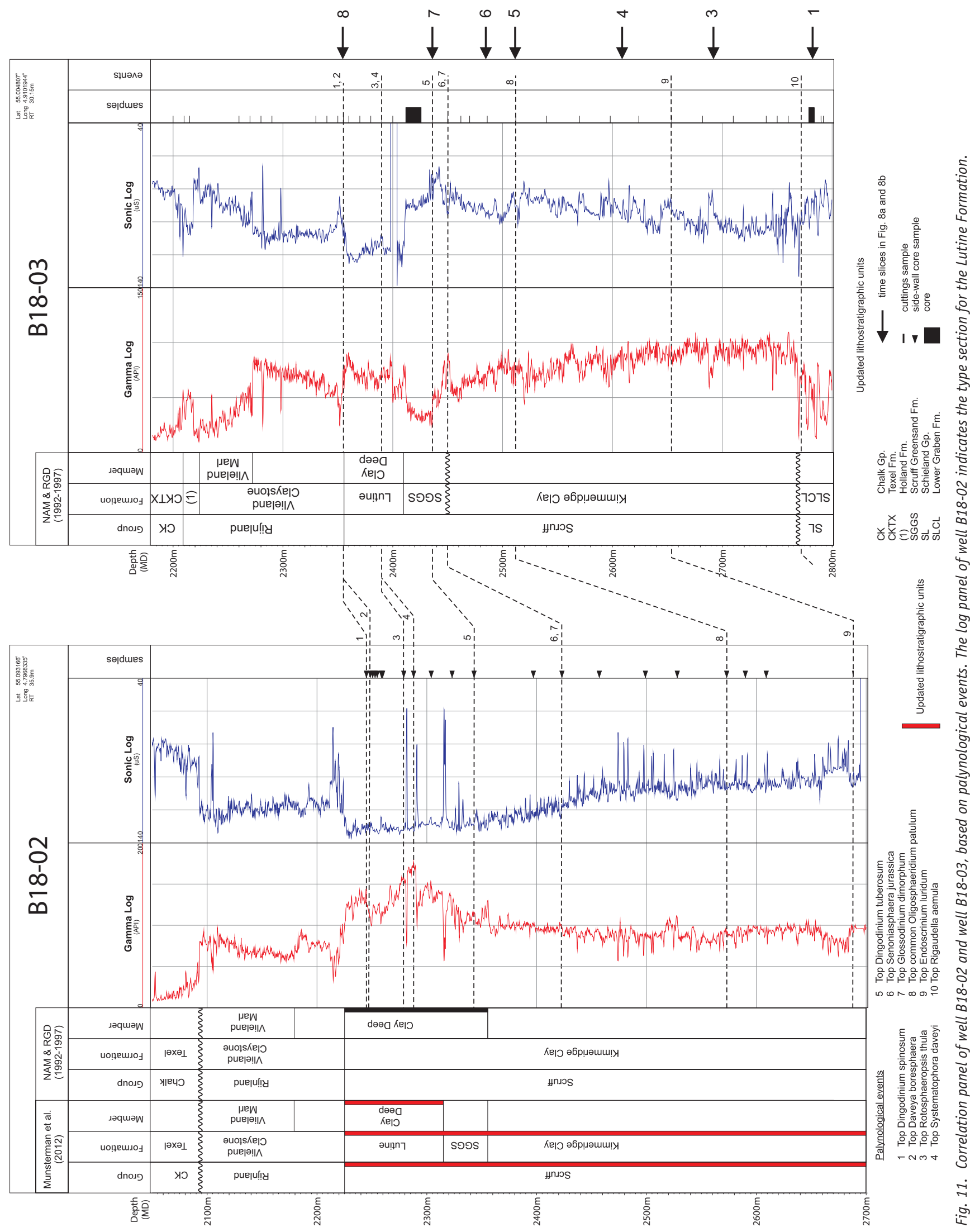




\section{Type section}

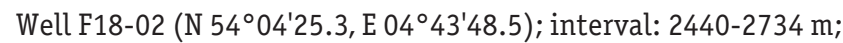
thickness: $294 \mathrm{~m}$ along hole (Appendix 2). Note: the Rifgronden Member was not distinguished in well F18-02.

\section{Additional Reference Section}

Well L03-01 (N 5356'55.4, E 04²0'22.0); interval 2542-2990 m; thickness: $448 \mathrm{~m}$ along hole.

\section{Definition}

The formation consists of alternating claystones, siltstones, sandstones and some minor coal. The siltstones and claystones are generally grey or variegated and become increasingly reddish-mottled towards the south in the L blocks. Siderite spherulites and concretions are common. The sands have been described as sheets, isolated and amalgamated channels (Van Adrichem Boogaert \& Kouwe, 1993). The GR-log pattern shows a change from predominantly funnel-shaped in the north (F17 block) to predominantly bell-shaped in the south (L blocks). Several intervals of dark-grey to black silty, carbonaceous, fossiliferous claystone with intercalated calcareous beds can be encountered in the formation.

\section{Lower boundary}

The Friese Front Formation rests with an unconformity on the marine claystones and carbonates of the Altena Group or on older Triassic or Permian units.

\section{Upper boundary}

Normally, the Skylge Formation (new formation, see below) overlies the Friese Front Formation conformably (Fig. 6). The Rijnland Group (Vlieland Sandstone Formation or Vlieland Claystone Formation) or the Scruff Greensand Formation (Stortemelk Member) occasionally rest unconformably on this formation if a prominent Late Kimmerian II unconformity is developed.

\section{Distribution}

The Friese Front Formation (F8a2-3) is restricted to the southern Dutch Central Graben and Terschelling Basin (blocks F17, F18, L01, L02, L03, L05, L06, M01, M04 and M07). In the upper parts the formation interfingers with the marine Scruff Group. It is a lateral equivalent of the Lower, the Middle Graben and the Puzzle Hole formations in the northern part of the Central Graben. The fault-controlled transition to the Puzzle Hole is located near the northern margin of the Terschelling Basin, in the F15-F17 blocks and is characterised by a sharp increase in the number of coal beds (from a few to 10-20/100 m), which can easily be discerned on logs (highly serrate in the Puzzle Hole Formation) and on seismic lines.

\section{Age}

Sequence 1 and 2 sensu Abbink et al., 2006: Late Callovian Late Kimmeridgian (Fig. 2). In the Terschelling Basin the Friese Front Formation is younger (Sequence 2) than in the Central Graben area (Sequence 1 and 2). In the southern part of the Dutch Central Graben the age is latest Callovian to Kimmeridgian. The top occurrence of Couperisporites jurassicus, Rotverrusporites granularis and Varirugosisporites granituberosus (LODs: L. Kimmeridgian, hudlestoni Ammonite Zone) fall within the formation.

\section{Palynofacies}

In the basal part (Rifgronden Member) the dinoflagellate cyst assemblages are very similar to those in the F blocks around the transition of the Lower to Middle Graben Formation. Characteristic cysts are: Rigaudella aemula, Liesbergia scarburghensis, Lithodinia jurassica and Wanaea. In upward direction the samples show a decreasing number of dinoflagellate cysts.

In the upper part (main Friese Front Member) the sporomorph associations are diversified and the fresh to brackish water algae Botryococcus is rare to common. Characteristic sporomorphs are e.g. Densoisporites minor, Leptolepidites cf. equatibossus, Precicatricosisporites, Retitriletes undulates, Rotverrusporites granularis, Varirugosisporites granituberosus and verrutrilites type 1084/5-8. The sediments, with locally minor coal layers and common lignitic matter, are exclusively terrestrial and indicate a non-marine (coastal) delta plain depositional environment. The presence of dinocysts and high numbers of Classopollis at the top of the formation in the southern part of block L02 and blocks L05 and L06 indicate a change to near-coastal marine environments. The marine influx at the top is associated with the onset of the Late Kimmeridgian hudlestoni MFS J66 of Partington et al. (1993). It marks the transition to the marine Noordvaarder Member of the Skylge Formation (marine Scruff Group).

\section{Depositional setting}

Non-marine (coastal) delta plain to lagoonal deposits.

\section{Rifgronden Member (SLCFR)}

The Rifgronden Member, defined by Van Adrichem Boogaert \& Kouwe (1993), is part of the Friese Front Formation.

\section{Derivatio nominis}

Named after the Borkummer Rifgronden, an area with a stony sea-bottom in the North Sea, south of the German Wadden island of Borkum.

\section{Type section}

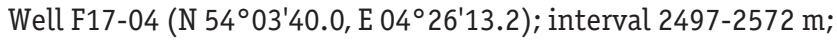
thickness: $75 \mathrm{~m}$ along hole (Van Adrichem Boogaert \& Kouwe, 1993, Annex G-8). 


\section{Additional Reference Section}

Well L05-04 (N 53ํ9'06.7, E 04² 24'13.3); interval 2817-2825 m; thickness: $8 \mathrm{~m}$ along hole (Van Adrichem Boogaert \& Kouwe, 1993, Annex G-7).

\section{Definition}

The member comprises dark-grey, carbonaceous, locally silty to sandy claystone, with thin intercalated beds of well-sorted, very fine to fine-grained sandstone, dolomite and coal. An up to $25 \mathrm{~m}$ thick interval with several thicker sandstone and coal beds is included in the member. It can be found some $20-40 \mathrm{~m}$ below the top of the formation in most sections, but is not encountered in reference well L05-04. Cored sections show bioturbated wavy and flaser bedding. The sandstone beds are cross-bedded. Internal coarsening upward trends are frequently observed (cores, funnel-shaped log patterns). This member is age equivalent of the Middle Graben Formation and the uppermost part of the Lower Graben Formation to the north.

\section{Lower boundary}

The lower boundary, with the Altena Group (dark-coloured marine shales), is unconformable and can be seen as a shift in sonic log patterns and as a seismic reflector.

\section{Upper boundary}

The upper boundary, with the main Friese Front (informal) Member, is placed at the base of the second thick sandstone interval in the type well, often marked by a resistivity-log peak (e.g. Van Adrichem Boogaert \& Kouwe, 1993; Annex G-8). Resistivity and sonic log readings above this boundary seem to shift and change slightly, but not uniformly. Upwards, the grain size of sandstone increases slightly, and the marine character disappears.

\section{Distribution}

The member is restricted to the southern Dutch Central Graben, Blocks F17-L05 (Fig. 8a1).

\section{Age}

Sequence 1 sensu Abbink et al. (2006): latest Callovian - Early Oxfordian age (Fig. 2). Characteristic dinocysts are Durotrigia filapicata (LOD: E. Oxfordian), Liesbergia scarburghensis, Rigaudella aemula and Wanaea (LOD: E. Oxfordian). Towards the top Gonyaulacysta jurassica and Rhynchodiniopsis cladophora become typical. Extreme abundance of the agglutinated foraminifer Ammodiscus sp. is a marked feature of this member.

\section{Palynofacies}

The sporomorph assemblages from the sandy claystones are rich and invariably predominated by Perinopollenites. Other taxa such as psilatriletes and Cerebropollenites are common, while more locally Callialasporites, Vitreisporites pallidus, Classopollis and a wide variety of spores, e.g. Neoraistrikia gristhorpensis, are fair to common. The dinocyst diversity is restricted, with Rhynchodiniopsis cladophora as a constant species. The depositional environment is considered to be restricted marine, most likely lagoonal with strong lowland, coastal and fluvial influence. The marine influence diminishes towards the south.

\section{Depositional setting}

Lagoonal.

\section{Scruff Group (SG)}

This group was defined by Herngreen \& Wong (1989). The Scruff Group comprises all predominantly marine formations of Late Jurassic - earliest Cretaceous age in the northern Dutch offshore.

\section{Derivatio nominis}

Named after the offshore Upper Scruff Bank in the North Sea, which lies adjacent to the reference well F03-03, NAM \& RGD (1980).

\section{Type section}

Well F03-03 (N 54 $50^{\prime} 45.5$, E 04 $42^{\prime} 29.3$ ); interval: 1682-2547 m; thickness: $865 \mathrm{~m}$ along hole (Van Adrichem Boogaert \& Kouwe, 1993, Annex G-2).

\section{Definition}

Group of formations deposited in a predominantly marine environment. The group consists of a succession of locally bituminous claystones with thin intercalated carbonate beds and glauconitic, sometimes argillaceous, fine- to coarse-grained sandstones.

\section{Lower boundary}

The group conformably overlies the (paralic to) terrestrial sands of the Schieland Group. Towards the basin margin this contact may become unconformable.

\section{Upper boundary}

The Scruff Group is mildly unconformably overlain by sediments of the Rijnland Group. The upper boundary coincides with the Sequence 3 / Sequence 4 transition (Fig. 2) sensu Abbink et al. (2006). It is associated with the Late Kimmerian unconformity. Generally, a change in colour and log patterns is seen at the contact. As a result of Sub-Hercynian/Laramide inversion tectonics, the Chalk or Lower North Sea groups can also be found overlying this group.

\section{Distribution}

The group is present in the Step Graben, Central Graben, Schill Grund Platform, Terschelling Basin and in the northern part of the Vlieland Basin (Figs 8a2-3 and 8b5-8). 


\section{Age}

Late Sequence 1, Sequence 2 and 3 sensu Abbink et al. (2006): Late Oxfordian - Ryazanian.

\section{Depositional setting}

The group comprises a variety of Late Jurassic to earliest Cretaceous marine environments from restricted (lagoonal) to open marine (outer shelf) conditions.

\section{Subdivision}

The Scruff Group is differentiated into four formations:

Scruff Group

Kimmeridge Clay Formation

Skylge Formation

Scruff Greensand Formation

Lutine Formation

SG

SGKI (amended)

SGSK (new formation)

SGGS (amended)

SGLU (new formation)

Here, the Kimmeridge Clay Formation is limited to the northern part of the Dutch Central Graben and Step Graben in late Sequence 1 and Sequence 2 sensu Abbink et al. (2006). The Clay Deep and Schill Grund members are excluded from the Kimmeridge Clay Formation and accommodated in a new formation, the Lutine Formation (Sequence 3). The new Skylge Formation is established to comprise all restricted to shallow marine Late Jurassic successions in the fringes of the Central Graben, Terschelling Basin and northern part of the Vlieland Basin during Sequence 2 sensu Abbink et al. (2006). The Scruff Greensand Formation is restricted to the shallow marine glauconitic sandstones of the northern Dutch offshore in Sequence 3 sensu Abbink et al. (2006).

\section{Kimmeridge Clay Formation (SGKI), amended}

The formation is included in the Scruff Group. The formation was defined by NAM \& RGD (1980) and amended/redefined by Herngreen \& Wong (1989) and by Van Adrichem Boogaert \& Kouwe (1993). The Clay Deep and Schill Grund members are transferred from the Kimmeridge Clay Formation (Van Adrichem Boogaert \& Kouwe, 1993) into the new Lutine Formation. Chrono- and lithostratigraphically both members do not fit with the Kimmeridge Clay Formation.

\section{Derivatio nominis}

Name derived from the British stratigraphic nomenclature where it is applied to similar argillaceous deposits which are wide-spread in the general North Sea area (NAM \& RGD, 1980).

\section{Type section}

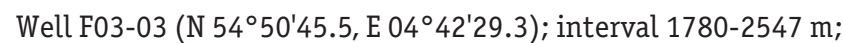
thickness: $767 \mathrm{~m}$ along hole (Van Adrichem Boogaert \& Kouwe, 1993, Annex G-2).

\section{Definition}

The formation occurs in the northern part of the Dutch Central Graben and Step Graben. The lithology consists of olive-grey, generally silty claystones with thin dolomite streaks (expressed on wire-line logs with a characteristic spiky appearance). Fossil fragments are common in lenses, lignite particles occur frequently. Dolomitic interbeds increase to the north. Towards the south, the claystones may become increasingly silty to sandy and the carbonate streaks and olive hue disappear gradually.

\section{Lower boundary}

The formation conformably overlies the marginal marine barrier island sandstones of the Upper Graben Formation (F03-03), the lacustrine to coastal Middle Graben Formation (F03-01), or the delta plain Puzzle Hole Formation. The Kimmeridge Clay Formation interfingers with the Puzzle Hole Formation and the Upper and Middle Graben formations (see Fig. 6).

\section{Upper boundary}

The formation is (slightly) unconformably overlain by the glauconitic Scruff Greensand Formation, or any younger unit, e.g. the new Lutine Formation (see below).

\section{Distribution}

The occurrence of the Kimmeridge Clay Formation is restricted to the northern part of the Central Graben (blocks A11, A12, A16, B14, B18, F03, F05 and F06) and locally to the adjacent Step Graben (Fig. 8a2-4 and 8b5-6). The formation shows a transgressive character from north to south. The equivalence to the Lola, Farsund and Mandal formations of the Danish and Norwegian sectors of the Central Graben was demonstrated by Michelsen \& Wong (1991).

\section{Age}

Sequence 1 and 2 sensu Abbink et al. (2006). The age is Late Oxfordian to Early Portlandian. The Late 0xfordian J54 MFS sensu Partington et al. (1993) forms the base of the Kimmeridge Clay Formation. Characteristic dinoflagellate cysts are Cribroperidinium longicorne, Dichadogonyaulax chondrum, D. pannea, Egmontodinium polyplacophorum, Endoscrinium galeritum, E. luridum, Epiplosphaera bireticulata, Glossodinium dimorphum, Gochteodinia mutabilis, (LOD: E. Portlandian), Gonyaulacysta jurassica, Histiophora ornata, Leptodinium arcuatum/eumorphum, L. subtile, Muderongia sp. A sensu Davey (1982; LOD: E. Portlandian), Occisucysta balios (LOD: L. Kimmeridgian), Oligosphaeridium patulum (acme), Perisseiasphaeridium pannosum (acme), Scriniodinium crystallinum, $S$. inritibile and Stephanelytron spp. The bisaccate dominated sporomorph assemblages also typically contain Callialasporites. Micropalaeontological assemblages contain Galliaecytheridea dissimilis, G. punctata, G. dorsetensis, Macrodentina cicatricosa and Eripleura eleanorae (all ostracods). 


\section{Palynofacies}

Well-preserved palynomorphs (including (very) common sporomorphs with high buoyancy in water and air (e.g. bisaccates)), near coastal taxa (such as Classopollis) and very common to abundant and diversified dinocysts indicate lowenergy middle to outer neritic shelf (open marine) conditions. Near the base of the formation low numbers of dinoflagellate cysts with a 'bloom' of Escharisphaeridia still suggests a depositional environment partially protected from open marine influence. Three major MFS sensu Partington et al. (1993) can be recognised: the Late 0xfordian $\mathrm{J} 54$ (serratum Ammonite Zone) and the Early Kimmeridgian $\mathrm{J} 63$ (eudoxus Ammonite Zone) and $\mathrm{J} 66$ (hudlestoni Ammonite Zone).

\section{Depositional setting}

The sediments of the Kimmeridge Clay Formation were deposited in an outer shelf setting. Dolomitic beds and structureless organic matter (SOM) indicate times of decreased input of clastics and stagnant water conditions with a stratified water column. The higher frequency of dolomitic beds and SOM in the north reflect a slightly deeper environment in the northern realm.

\section{Skylge Formation (SGSK), new formation}

This new formation is included in the Scruff Group (Table 1 and Fig. 6). It comprises all marine successions from the Terschelling and Vlieland basins in Sequence 2 (Fig. 2) sensu Abbink et al. (2006). Scattered occurrences are also recorded at the fringes of the Central Graben. Four members are recognised in the Skylge Formation: the 0yster Ground, Terschelling Sandstone, Noordvaarder and Lies members (Fig. 6).

The 0yster Ground and Terschelling Sandstone members are transferred from the Friese Front Formation (mainly continental Schieland Group) to the new Skylge Formation, because of their restricted marine character.

The Noordvaarder Member includes the predominantly sandy part of the former Scruff Argillaceous Member and the underlying difficult to distinguish Scruff Basal Sandstone Member (Fig. 2). The recognition of the Scruff Basal Sandstone Member as a separate unit is abandoned here.

The lateral clayey facies of the former Scruff Argillaceous is attributed to the Lies Member (Figs 2 and 6). In addition, the informal main Kimmeridge Clay Member sensu Van Adrichem Boogaert \& Kouwe (1993) in the southern Central Graben, the Terschelling and Vlieland basins is also included in the Lies Member. The Kimmeridge Clay Formation (amended) is currently restricted to the northern Central Graben. The term Scruff Argillaceous Member is also abandoned here.

The stratigraphic interval from 2312 till $2565 \mathrm{~m}$ of well L06-02 is presented as the new type section for the Skylge Formation and its attributed members (Fig. 9). Cores taken from within this interval enable the description of the type section in detail. An impression of a core description is given in Plate 1. A critical note on this type section is the occurrence of faults in the Terschelling Sandstone Member, which casts doubt on the assumption that the type section represents the true stratigraphic thickness. However, for definition of a sound lithological description this well seems appropriate, taking into account the surrounding wells where a similar succession can be observed.

\section{Derivatio nominis}

Named after the Frysian name of the Wadden island Terschelling.

\section{Type section}

L06-02 (N 5348'53.7, E 045'19.97); interval 2318-2565 m; thickness: $247 \mathrm{~m}$ along hole (Fig. 9).

\section{Additional Reference Section}

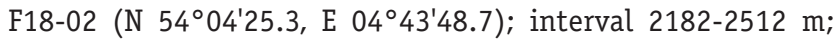
thickness: $330 \mathrm{~m}$ along hole (Appendix 2).

\section{Definition}

Succession of alternating slightly silty to sandy claystones, argillaceous and/or non-argillaceous glauconitic sandstones. Bioturbation is often present. Locally pyrite, lignite and/or shell fragments are present.

\section{Lower boundary}

The Skylge Formation conformably overlies the Friese Front Formation (boundary: top of the first variegated or grey, nonmarine clay-/siltstones or thick sand bed, Fig. 6).

\section{Upper boundary}

The transition coincides with the Sequence 2 / Sequence 3 boundary (Fig. 2) sensu Abbink et al. (2006). In the southern Central Graben the formation is unconformably overlain by the Scruff Greensand Formation (Figs 6 and 7). The upper boundary with the Scruff Greensand Formation is recorded by a funnelshaped GR-log pattern, resulting from the upward decreasing clay content. This change is also well shown on the porosity log. Sequences 2 and 3 are relatively thick in the Terschelling Basin as compared to the Central Graben. Deposition was continuous in the depocentre of the Terschelling Basin (Abbink et al., 2006).

\section{Distribution}

The formation occurs at the fringes of the Central Graben (e.g. blocks B14, F11 and F12), the Terschelling (see Fig. 8b6) and Vlieland basins (blocks F15, F17, F18, G16, L02, L03, L05, L06, L09, L12, L15, M01, M04 and M07). In the Terschelling Basin the basal part of the Skylge Formation may also interfinger with the top of the Friese Front Formation. The Kimmeridge Clay Formation in the northern part of the Central Graben is the open marine equivalent of the restricted to shallow marine Skylge Formation. 


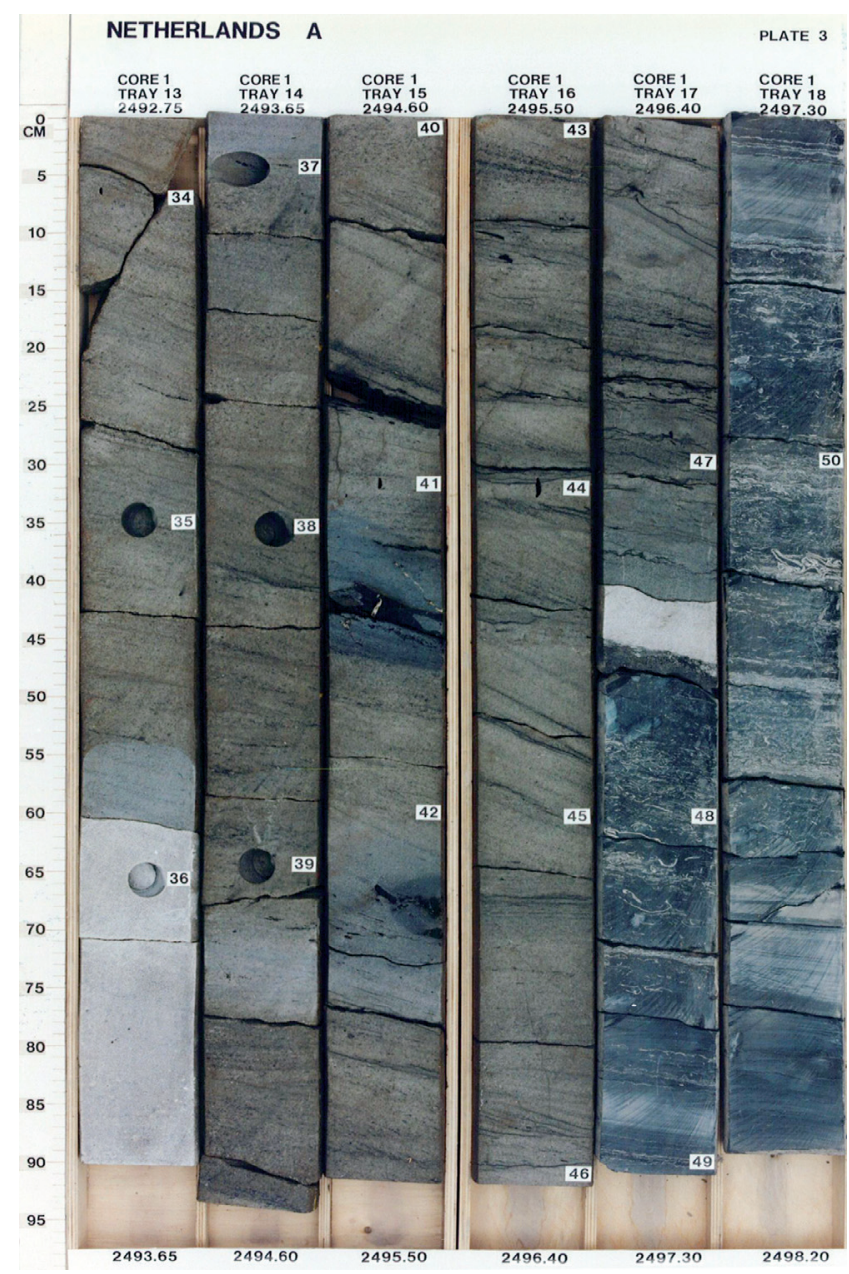

Plate 1. Photograph of the core section over the lithostratigraphic boundary of the Terschelling Sandstone Member and the Oyster Ground Mbr. The Terschelling Sandstone Mbr is characterised by fine to medium grained sandstones which are horizontally, low angle and cross laminated sandstone beds. Burrows are present. Note the common occurrence of coal clasts. The true thickness of this member may be reduced by faulting. The lithostratigraphic boundary is visible at $2496.95 \mathrm{~m}$ at the abrupt change from the sandstone to black claystone in a downward direction. The claystone is subtly laminated. Remarkable are the interbedded bioclastic layers of monotypical shell hash (cf. Neomiodon Oyster).

\section{Age}

Sequence 2 sensu Abbink et al. (2006): late Early Kimmeridgian Early Portlandian, eudoxus-anguiformis Ammonite zones (Fig. 6). The base of the formation is associated with the late Early Kimmeridgian J63 MFS sensu Partington et al. (1993). The top coincides with the Sequence 2/Sequence 3 boundary sensu Abbink et al. (2006) in the anguiformis Ammonite Zone and is associated with the Early Portlandian J73 MFS sensu Partington et al. (1993).

\section{Depositional setting}

Restricted to shallow marine conditions.

\section{Oyster Ground Member (SGSKO), revised name and classification}

The Oyster Ground Claystone Member is defined by Van Adrichem Boogaert \& Kouwe (1993; Fig. 1). It includes deposits from the southern Dutch Central Graben as well as the Terschelling Basin. Since the member does not always consist of claystones, the lithological affix has been dropped here. In the southern part of the Terschelling Basin (M4 and M7 blocks) and also in several wells in the southeastern area of the Dutch Central Graben (blocks L02 and L03 p.p.) a sandy subfacies is described. The member is transferred from the Friese Front Formation to the new Skylge Formation, because of the restricted marine character. The Skylge Formation is part of the marine Scruff Group.

\section{Derivatio nominis}

Named after the 0yster Ground, a fishing ground situated at

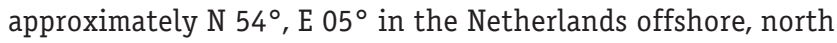
of the Wadden island Terschelling.

\section{Type section}

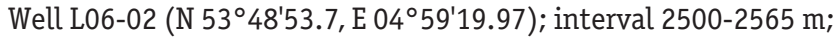
thickness: $65 \mathrm{~m}$ along hole (Fig. 9).

\section{Additional section}

Well F18-02 (N 54º4'25.3, E 04 43'48.7); interval 2440-2512 m; thickness: $72 \mathrm{~m}$ along hole (Appendix 2).

\section{Definition}

Medium to dark brown-grey claystones, non- to slightly silty, non-calcareous, lignitic and fossiliferous (thick pelecypod shell fragments, ostracods). Some limestone beds have been encountered. Thick sand beds, characteristic for the main Friese Front Formation, are absent. Along the basin margins the lithology may change into a more sandy subfacies, like in the southern Terschelling Basin. The member can be separated from the Kimmeridge Clay Formation by its marginal marine depositional environment and geographical setting.

\section{Lower boundary}

The base of the Oyster Ground Member in the southern Dutch Central Graben and the Terschelling Basin is the conformable contact with the informal main Friese Front Member (boundary: top of the first variegated or grey, non-marine clay-/siltstones or thick sand bed). In the Terschelling Basin the Oyster Ground Member may interfinger with the Friese Front Formation.

\section{Upper boundary}

The top is generally marked by a conformable contact with massive glauconitic sands of the overlying Noordvaarder Member in blocks F15 and F18 or the Terschelling Sandstone Member in blocks L03 and L06. This contact may locally become 
unconformable in the southern Central Graben (blocks L02-L05) where it is covered by the Stortemelk Member (e.g. L05-01). In parts of blocks L03 and L09 the Oyster Ground Member interfingers with the coarse-grained coastal clastics of the Terschelling Sandstone Member (Fig. 6).

\section{Distribution}

The member is restricted to the southern Dutch Central Graben, blocks F15, F17, L02 and the Terschelling Basin, blocks F18, L03, L06, M01, M04 and M07 (Figs 8a4 and 8b5). In the southwest, the member's lateral equivalent is the main Friese Front Member. The Kimmeridge Clay Formation in the northern Dutch Central Graben is the open marine equivalent of the restricted marine Oyster Ground Member.

\section{Age}

Sequence 2 sensu Abbink et al. (2006): late Early - early Late Kimmeridgian (Fig. 2). Age-diagnostic dinoflagellate cysts are present but rare, like Dichadogonyaulax pannaea (FOD: late Early Kimmeridgian), Senoniasphaera jurassica and Gochteodinia mutabilis (FOD: L. Kimmeridgian). Time significant sporomorphs are Kraeuselisporites huntii (FOD: late Early Kimmeridgian) and Couperisporites jurassicus. The frequent occurrence of ostracods such as Macrodentina rugulata, M. transiens, Cytheropteron purum, Paranotacythere pustulata, Klieana calyptroides and Exophtalmocythere? gigantean verifies the interpretation.

\section{Palynofacies}

All marine dinocyst assemblages from the 0yster Ground Member, often with almost monospecific occurrence of species, indicate a marginal to restricted marine (lagoonal) setting. The late Early Kimmeridgian J63 MFS sensu Partington et al. (1993) correlates to the base 0yster Ground Member. This MFS is associated with the eudoxus Ammonite Zone. Intensifying of the Late Jurassic arid phase, marked by the Late Kimmeridgian scitulus climate shift is also recorded within this member. In the sporomorph record it is reflected by the change in genera dominance from Perinopollenites to Classopollis.

\section{Depositional setting}

Lithology, fossils, lignite and regional palaeogeography suggest that the Oyster Ground Member was deposited in restricted lagoon-like conditions with washover deposits. The monotypical thin-walled shell assemblages confirm a restricted marine setting.

\section{Terschelling Sandstone Member (SGSKT), revised classification}

The Terschelling Sandstone Member is defined by Van Adrichem Boogaert \& Kouwe (1993; Fig. 1). The member is included in the Skylge Formation, Scruff Group (Fig. 6).

\section{Derivatio nominis}

Named after the Terschelling Basin, where this member is typically developed.

\section{Type section}

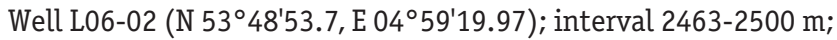
thickness: $37 \mathrm{~m}$ along hole (Fig. 9).

\section{Additional section}

Well L03-01 (N 5356'55.4, E 04²40'22.0); interval: 2399-2482 m; thickness: $83 \mathrm{~m}$ along hole (Van Adrichem Boogaert \& Kouwe, 1993, Annex G-4).

\section{Definition}

Fine- to medium-grained sandstone (occasionally up to coarse sand and gravel), well to poorly sorted. Carbonate cement, glauconite and lignite are common. The sandstones predominantly show fining but locally coarsening upward trends. Deposition mainly in the form of sheets and channels, separated by thin intervals of claystones. Note that the Terschelling Sandstone Member in the former type well L09-02 (interval 3028-3054 m) is not the most representative section. In this well the Terschelling Sandstone Member is unconformably underlain by the Aalburg Formation. It was selected due to the lack of public wells in the early nineties. A more appropriate type section is L06-02 (interval 2463-2500 m), although the true vertical thickness of this member may be reduced by faulting.

\section{Lower boundary}

The conformable basal contact with the 0yster Ground Member is characterised by a sharp downhole change to finer-grained deposits (base of the sandstone bed), the appearance of restricted-marine (lagoonal) fossils, a change towards higher $G R$ log readings and a more serrated sonic log pattern. In the type section well L06-02, the member unconformably rests on the Altena Group. In the deepest part of the Terschelling Basin, in well L03-01, interfingering is shown with the 0yster Ground Member. The Terschelling barrier sands in well L03-01 alternate with fine-grained lagoonal sands.

\section{Upper boundary}

The member is conformably overlain by the shallow marine calcareous claystones of the Lies Member (Figs 6 and 9). The top of the Terschelling Sandstone is diachronous. The youngest (latest Kimmeridgian) successions occur in the southern Terschelling Basin, blocks L06 and M04.

\section{Distribution}

The Terschelling Sandstone is deposited in the southeastern Dutch Central Graben and the Terschelling Basin, blocks L02, L03, L05, L06, L09, M01, M04 and M07 (Fig. 8b5-6). 


\section{Age}

Sequence 2 sensu Abbink et al. (2006): Late Kimmeridgian. The top of the member is diachronous. In general the top coincides with the Late Kimmeridgian J66 MFS sensu Partington et al. (1993), but in the southern Terschelling Basin (blocks L06 and M04) the top is associated with the latest Kimmeridgian 371 MFS sensu Partington et al. (1993). The latest Kimmeridgian is characterised by the presence (FOD) of Muderongia sp. A sensu Davey (1982).

\section{Palynofacies}

Dinocyst assemblages are relatively poor and characterised by Cribroperidinium (dominant), while euryhaline Dichadogonyaulax pannea is sometimes very abundant. Other characteristic types: Kleithriasphaeridium porosispinum (only in the upper part), Systematophora, Hystrichodinium, Rotosphaeropsis thula and Senoniasphaera jurassica. Pollen assemblages indicate a hot and arid climate in the hinterland.

\section{Depositional setting}

In most cases, e.g. in wells L06-02, L06-03 and M01-01, the sediments of this member are interpreted to be deposited as a barrier island complex, including shoreface to foreshore and washover fans environments, protecting the restricted marine (lagoonal) setting of the 0yster Ground.

\section{Noordvaarder Member (SGSKN), new member}

The member is part of the Skylge Formation, Scruff Group (Table 1 and Fig. 6). The Noordvaarder Member includes the predominantly sandy part of the former Scruff Argillaceous Member and the underlying difficult to distinguish Basal Sandstone Member. The Basal Sandstone Member is abandoned here. The lateral clayey facies of the former Scruff Argillaceous is attributed to the Lies Member (Fig. 9).

\section{Derivatio nominis}

Named after the shoal in the western part of the Wadden island Terschelling.

\section{Type section}

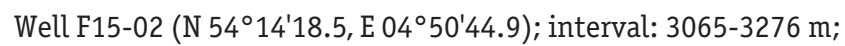
thickness: $211 \mathrm{~m}$ along hole (Appendix 1).

\section{Definition}

Section of moderately to well-sorted, greenish-grey, slightly argillaceous, occasionally calcite cemented, glauconitic sandstones. Sediments show bioturbation and are locally pyritic, lignitic, and/or characterised by shell debris.

\section{Lower boundary}

The lower boundary with the 0yster Ground Member (Skylge Formation) is marked by a sharp downward increase in GR readings, although a gentle funnel shape can be observed in the uppermost parts of the 0yster Ground Member in some wells.

\section{Upper boundary}

The upper boundary with the Scruff Spiculite Member is marked by a funnel-shaped GR-log pattern, resulting from the upward decreasing clay content (Van Adrichem Boogaert \& Kouwe, 1993; Annex G-5).

\section{Distribution}

The member is recorded at the fringes of the Central Graben (e.g. blocks B14 and F11) and in the north-western Terschelling Basin, blocks F15, F17, F18 and G16 (Fig. 8b6).

\section{Age}

Sequence 2 sensu Abbink et al. (2006): late Kimmeridgian - Early Portlandian, wheatleyensis/hudlestoni-anguiformis Ammonite zones (Fig. 6). The top coincides with the Sequence 2/Sequence 3 boundary sensu Abbink et al. (2006). The base is associated with the Late Kimmeridgian J66 MFS sensu Partington et al. (1993). Chronostratigraphic significant dinoflagellate cysts are: Dichadogonyaulax pannaea, Glossodinium dimorphum (LODs: late Early Portlandian, anguiformis Ammonite Zone), Kleithriasphaeridium porosispinum (FOD: Late Kimmeridgian), Muderongia sp. A in Davey (1982), Rotosphaeropsis thula and Senoniasphaera jurassica (LOD: late Early Portlandian, anguiformis Ammonite Zone).

\section{Palynofacies}

The sporomorph diversity is low and dominated by Classopollis. Other sporomorphs are bisaccates, Perinopollenites, psilatriletes, Gleicheniidites, Callialasporites and Cerebropollenites. The number of dinocysts is poor to moderate, but the variety is relatively good. Additional characteristic marine dinoflagellate cysts (see also Age) are: Dichadogonyaulax culmula and Gochteodinia mutabilis. More frequent at the base of the member are Cribroperidinium and Sentusidinium. The latter genera are indicative of very shallow marine settings.

\section{Depositional setting}

The sands were deposited in a shallow marine environment, ranging from offshore to lower shore face.

\section{Lies Member (SGSKL), new member}

The member is classified in the Skylge Formation, Scruff Group (Fig. 6). The Lies Member comprises the clayey succession of the former Scruff Argillaceous Member and also includes the southern extension of the informal main Kimmeridge Clay Member sensu Van Adrichem Boogaert \& Kouwe (1993) in the southern Central Graben, the Terschelling and Vlieland basins (Fig. 1). The Kimmeridge Clay Formation (amended) is currently restricted to the northern Central Graben (see above). The lateral 
sandy facies of the former Scruff Argillaceous is attributed to the Noordvaarder Member (Fig. 9). The Scruff Argillaceous Member has been abandoned.

\section{Derivatio nominis}

Named after the village Lies on the Wadden island Terschelling.

\section{Type section}

Well L06-02 (N 5348'53.7, E 04 59'19.97); interval 2318-2463 m; thickness: $145 \mathrm{~m}$ along hole (Fig. 9).

\section{Definition}

The member consists of bioturbated silty to sandy claystones. Locally, the member comprises glauconitic, pyritic and carbonate streaks. The GR-logs show fining and coarsening upward trends. The top of this member particularly demonstrates a coarsening upward trend in GR-log pattern.

\section{Lower boundary}

The Lies Member diachronously overlies the Terschelling Sandstone Member; the base of the Lies Member is younger in the southern part of the Terschelling Basin, blocks L06 and M04. The lower contact with the Terschelling Sandstone Member is conformable and marked by a downward drop in GR-log readings (bell-shape).

\section{Upper boundary}

The upper boundary with the Spiculite Member is marked by a funnel-shaped GR-log pattern, resulting from the upward decreasing clay content. This change is also well shown on the porosity log. The transition coincides with the Sequence 2 / Sequence 3 boundary (Fig. 2) sensu Abbink et al. (2006).

\section{Distribution}

The Lies Member is deposited in the south-eastern part of the Dutch Central Graben, Terschelling and Vlieland basins (blocks L02, L03, L06, L12, L15, M01 and M04 (Fig. 8b6)).

\section{Age}

Sequence 2 sensu Abbink et al. (2006): late Kimmeridgian - Early Portlandian, wheatleyensis/hudlestoni-anguiformis Ammonite zones. The base of the Lies Member is diachronous (Fig. 6). In the southern Terschelling Basin the age of the base is younger and associated with the latest Kimmeridgian J71 MFS sensu Partington et al. (1993). The top of the Lies Member coincides with the boundary between Sequence 2 and 3 sensu Abbink et al. (2006) in the anguiformis Ammonite Zone. The FODs (First 0ccurrence Datum) of Kleithriasphaeridium porosispinum and Rotosphaeropsis thula indicate late Late Kimmeridgian (hudlestoni Ammonite Zone) or a younger age.

\section{Palynofacies}

Saccate pollen (bisaccates, including Vitreisporites pallidus and Cerebropollenites), Classopollis (e.g. C. echinatus/hammenii) and Perinopollenites are very common to abundant. Psilatrilete spores, including Gleicheniidites, may also reach high numbers. Additional chronostratigraphic important dinoflagellate cysts are: Dichadogonyaulax pannea, Glossodinium dimorphum, Gochteodinia mutabilis, Muderongia sp. A in Davey (1982) and Senoniasphaera jurassica.

\section{Depositional setting}

The sediments are considered to be deposited in the offshoreshelf environment.

\section{Scruff Greensand Formation (SGGS), amended}

The formation is included in the Scruff Group (Table 1).The formation was defined by Herngreen \& Wong (1989) and amended by Van Adrichem Boogaert \& Kouwe (1993; Fig. 1). Here, the formation is amended to comprise all shallow marine glauconitic sandstones of the Central Graben, Schill Grund Platform, Step Graben, Terschelling and Vlieland basins (Fig. 6) in Sequence 3 sensu Abbink et al. (2006). Two members are recognised in the Scruff Greensand Formation: the Scruff Spiculite and Stortemelk members (Fig. 6). The Scruff Basal Sandstone and Scruff Argillaceous Members are abandoned (Fig. 2). The sandy part of the Scruff Argillaceous Member and the Scruff Basal Sandstone are integrated in the new Noordvaarder Member (Fig. 6). The Noordvaarder Member is classified in the Skylge Formation, which is part of Sequence 2.

\section{Derivatio nominis}

Named after the offshore Upper Scruff Bank in the North Sea near well F03-03.

\section{Type section}

Well F15-02 (N 54 $14^{\prime} 18.5$, E 04 50'44.9; interval 3021-3065 m; thickness: $44 \mathrm{~m}$ along hole (Appendix 1).

\section{Additional section}

Well F18-01 (N 54은 54.5 , E 04 44'32.1); interval 2175-2230 m; thickness: $55 \mathrm{~m}$ along hole (Appendix 3).

\section{Definition}

The formation consists of grey-green shallow marine finegrained sandstones that are often intensely bioturbated. The glauconite content is generally high and locally spiculites are abundant at the base of the section. The sandstones may be slightly argillaceous and/or calcareous.

\section{Lower boundary}

The Scruff Greensand / Skylge Formation transition (Fig. 6) is associated with the Sequence 2 / Sequence 3 boundary sensu 
Abbink et al. (2006). Sequences 2 and 3 are relatively thick in the Terschelling Basin as compared to the Central Graben. A hiatus occurs in the Central Graben, but deposition was continuous in the depocentre of the Terschelling Basin (Abbink et al., 2006). The lower boundary with the Skylge Formation is marked by an increase in GR-log readings, resulting from the downward increasing clay content. The occurrence of the sponge spiculae at the base of the Scruff Greensand Formation may locally be taken as an additional criterion.

\section{Upper boundary}

The Scruff Greensand Formation is generally conformably overlain by the Lutine Formation (Fig. 6). The contact is diachronous. In the northernmost part of the Central Graben the base of the Lutine Formation is older. This upper contact is marked by a general rise in GR-log readings. In the southern Dutch Central Graben an unconformable upper contact with the Vlieland Claystone Formation (Rijnland Group) may locally be present.

\section{Distribution}

The Scruff Greensand Formation is present in, although not continuously, the Central Graben, Schill Grund Platform, Step Graben and Terschelling Basin, blocks A12-A15, B18 to M07 (Fig. 8b7-8). In the northern part of the Dutch Central Graben the formation occurs over the salt dome of the F03-FA field, where it forms a gas reservoir. Well-developed sands are absent in the central part of the Dutch Central Graben but local sandy sections have been observed along the margins of the basin (e.g. F11-03 and F12-03). In the L12 and L15 blocks the formation interfingers with the paralic Zurich Formation, into which it shales out.

\section{Age}

Sequence 3 sensu Abbink et al. (2006): latest Early Portlandian earliest Late Ryazanian, oppressus-icenii Ammonite zones. The age of the top of the formation is diachronous. In the southern part of the Central Graben and the Terschelling Basin the top of the Scruff Greensand Formation has an earliest Late Ryazanian age (icenii Ammonite Zone), while in the northernmost part of the Central Graben the youngest occurrence reaches the Late Portlandian.

\section{Depositional setting}

Shallow marine, shoreface to offshore environment.

\section{Scruff Spiculite Member (SGGSP)}

The Scruff Spiculite Member is defined by Van Adrichem Boogaert \& Kouwe (1993; Fig. 1). The member is included in the Scruff Greensand Formation, Scruff Group.

\section{Derivatio nominis}

Named after the offshore Upper Scruff Bank near well F03-03.

\section{Type section}

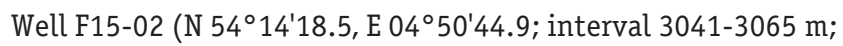
thickness: $24 \mathrm{~m}$ along hole (Appendix 1).

\section{Additional section}

Well F18-01 (N 5405'54.5, E 04 44'32.1); interval 2193-2230 m; thickness: $37 \mathrm{~m}$ along hole (Appendix 3).

\section{Definition}

The member consists of light green-grey, fine-grained, glauconitic and slightly argillaceous intensely bioturbated sandstones. Primary sedimentary structures are absent. The name of the unit refers to the abundance of spicules in the sediment. Spicules are the skeletal remains of sponges. The sponge spicules may make up the bulk of the framework forming a bioclastic sandstone.

\section{Lower boundary}

The lower boundary with the Noordvaarder and the Lies members is marked by an increase in GR-log readings, resulting from the downward increasing clay content. The boundary coincides with the Sequence 2 / Sequence 3 boundary sensu Abbink et al. (2006). Sequences 2 and 3 are relatively thick in the Terschelling Basin as compared to the Central Graben. A hiatus occurs in the Central Graben, but deposition was continuous in the depocentre of the Terschelling Basin (Abbink et al., 2006). The abundant occurrence of the sponge spiculae or its moulds may be taken as an additional criterion.

\section{Upper boundary}

The member is mildly unconformably overlain by the Stortemelk Member. The boundary is placed at the transition of a cylinderor funnel-shaped GR-log pattern (Scruff Spiculite Member) to a bell-shaped pattern (Stortemelk Member). This level is nearly always marked by a clear GR-log peak, belonging to the Stortemelk Member.

\section{Distribution}

The Scruff Spiculite Member is developed in the southern Dutch Central Graben and in the Terschelling Basin, blocks F11 (p.p.), F12, F15, F18, L02 (p.p.), L03, L05 (p.p.), L06 (p.p.), M01, M04 and M07 (Fig. 8b7).

\section{Age}

Sequence 3 sensu Abbink et al. (2006): latest Early Portlandian Early Ryazanian, oppressus-base kochi Ammonite Zone. The base of the member is characterised by the acme of the dinocyst Cribroperidinium hansenii (oppressus-primitivus Ammonites zones). The LOD (= runctoni Ammonite Zone) of Gochteodinia virgula is recorded in this unit. The transition from the Spiculite to the Stortemelk member coincides with the Early Ryazanian kochi climate shift. 


\section{Palynofacies}

The acme of Cribroperidinium hansenii at the base of this member indicates very specific palaeoenvironmental conditions, reflecting a semi-enclosed shallow marine setting enriched in nutrients. Other important dinocysts are: Apteodinium spongiosum, Dichadogonyaulax pannea, Dingodinium spinosum, Gochteodinia villosa, Perisseiasphaeridium insolitum and Rotosphaeropsis thula. The sporomorphs are dominated by Classopollis, indicating a near-coastal deposition. Pollen indicate a hot and arid climate.

\section{Depositional setting}

The sediments of this formation were deposited in a (offshore to) shoreface environment. Facies change laterally from relatively clean 'bioclastic' sandstone to an argillaceous sandstone reflecting the position of the depositional area on the basin floor topography (Abbink et al., 2006). A semi-enclosed shallow marine environment is envisaged.

\section{Stortemelk Member (SGGSS)}

The member is defined by Van Adrichem Boogaert \& Kouwe (1993; Fig. 1). It is the uppermost member of the Scruff Greensand Formation, Scruff Group (Fig. 6). The second additional reference section, well Vlieland 0ost-01, interval 2330-2393 m (in Van Adrichem Boogaert \& Kouwe, 1993) is rejected. The purely continental sporomorph assemblages with minor amounts of near-coastal elements do not support the assignment to this unit (Herngreen et al., 2000). Marine influence such as acritarchs and dinoflagellate cysts has not been recorded. Attribution to the overlying Zurich Formation is more likely (see Annex G-24 in Van Adrichem Boogaert \& Kouwe, 1993).

\section{Derivatio nominis}

Named after the Stortemelk, a channel of the outer tidal delta between the Wadden islands of Vlieland and Terschelling.

\section{Type section}

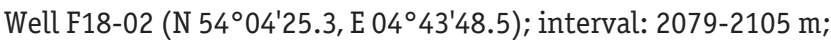
thickness: $26 \mathrm{~m}$ along hole (Appendix 2).

\section{Additional section}

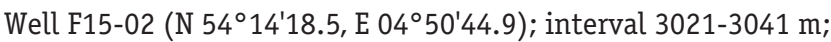
thickness: $20 \mathrm{~m}$ along hole (Appendix 1).

\section{Definition}

Section of fine- to very fine-grained, argillaceous sandstones with intense bioturbation. The sands are often slightly calcareous, glauconitic, with thin streaks of lignite. Cores show some intercalations of up to coarse, glauconitic and sometimes argillaceous sandstone.

\section{Lower boundary}

In the Terschelling Basin the lower boundary of this member is characterised by a mild unconformity with underlying Scruff Spiculite Member or undifferentiated Scruff Greensand Formation (Fig. 6). The boundary is placed at the discontinuity (consistent basal peak) of the GR-log. The GR-log shows lower values in the Spiculite Member, due to a decreasing argillaceous content. The Stortemelk Member has a distinct bell-shaped GR-log pattern. In the case of a contact with the Spiculite Member, a downhole increase in the sponge spiculae content may be taken as an additional criterion. In the southern Central Graben the base of the Stortemelk Member may be unconformably underlain by the Skylge or Friese Front Formation, due to the development of a prominent Late Kimmerian II unconformity (Table 1 and Fig. 6). A diagnostic log kick on the gamma log at the base suggests a cemented horizon.

\section{Upper boundary}

The Stortemelk Member is conformably overlain by the Lutine Formation, Schill Grund Member (Fig. 6). This upper contact is marked by a general rise in GR-log readings. In the southern Dutch Central Graben an unconformable upper contact with the Vlieland Claystone Formation (Rijnland Group) may be possible locally.

\section{Distribution}

The Stortemelk Member is developed in the southern Dutch Central Graben and Terschelling Basin, blocks F15, F17, F18, L02, L03, L06, L09 and M01. In the L12 and L15 blocks this member interfingers with the paralic Zurich Formation, into which it shales out. To the north it shales out into the Schill Grund Member.

\section{Age}

Sequence 3 sensu Abbink et al. (2006): late Early - earliest Late Ryazanian, kochi-icenii Ammonite zones. The base of the Stortemelk Member is associated with the Early Ryazanian kochi climate shift. Chronostratigraphic important dinoflagellate cysts are: Batioladinium radiculatum (FOD: E. Ryazanian, runctoni Ammonite Zone), Daveya boresphaera (kochi-stenomphalus Ammonite zones) and Systematophora daveyi (LOD: Early Ryazanian, kochi Ammonite Zone).

\section{Palynofacies}

The sporomorphs are dominated by psilatrilete spores, bisaccates, Classopollis and Perinopollenites in varying combinations. Compared to the underlying Scruff Spiculate palynofacies the relative number of Classopollis is lower (Early Ryazanian kochi climate shift). The arid phase ended, and the climate returned to wet, tropical conditions ('Wealden facies'). Additional marine dinocyst taxa are: Circulodinium compta, Cribroperidinium, Dingodinium spinosum, Gochteodinia villosa, Kleithriasphaeridium porosispinum, Oligosphaeridium diluculum and Rotosphaeropsis 
thula. Deposition took place in a shallow marine environment with a strong terrestrial input.

\section{Depositional setting}

Shoreface to offshore setting.

\section{Lutine Formation (SGLU), new formation}

The formation is included in the Scruff Group (Table 1; Fig. 6). It comprises the Clay Deep and Schill Grund members. These members are transferred from the Kimmeridge Formation into the new Lutine Formation, because both were separated chronostratigraphically and geographically from the Kimmeridge Clay Formation. In addition, the characteristic thin dolomite streaks of the Kimmeridge Clay Formation are missing in the Lutine Formation and the latter shows higher GR-log values. The Scruff Greensand Formation separates the Clay Deep and Schill Grund members (Fig. 6).

\section{Derivatio nominis}

Named after the HMS Lutine, a frigate of the Royal British Navy, (although originally a French naval ship, launched at Toulon in 1779) that was wrecked in 1799 in a shallow channel called the IJzergat, which has completely silted up, between the Dutch Wadden islands of Vlieland and Terschelling.

\section{Type section}

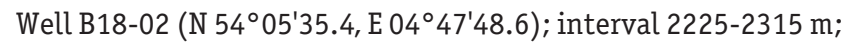
thickness: $90 \mathrm{~m}$ along hole (Fig. 11).

\section{Additional section}

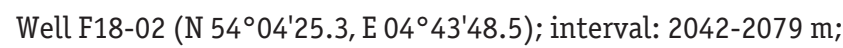
thickness: $37 \mathrm{~m}$ along hole (Appendix 2).

\section{Definition}

In the northern part of the Dutch Central Graben the formation consists of (brownish-) grey to black bituminous claystones (Clay Deep Member). South of blocks F11/F12 the colour changes into olive-grey to grey-brown and the clays become more silty to very fine sandy and less bituminous (Schill Grund Member; Fig. 6).

\section{Lower boundary}

In the northern Central Graben the Lutine Formation rests unconformably on the Scruff Greensand or Kimmeridge Clay formations (Fig. 6). Occasionally the Lutine Formation may interfinger with the Scruff Greensand Formation. The bituminous shales show a less spiky appearance on the wire-logs (due to the absence of thin dolomite streaks), and higher values on the GR and resistivity readings than the underlying Kimmeridge Clay Formation. The boundary with the glauconitic Scruff Greensand Formation in the southern part of the Central Graben and Terschelling Basin is conformable (Fig. 6).

\section{Upper boundary}

The upper boundary coincides with the Sequence 3 / Sequence 4 transition sensu Abbink et al. (2006; Figs 2 and 6). It is associated with the Late Kimmerian unconformity. The formation is unconformably overlain by the Rijnland, Chalk or Lower North Sea groups. In the northern Dutch Central Graben this boundary is shown by upward decreasing values on the GR and the resistivity logs. In the southern Central Graben and Terschelling Basin the top may be more difficult to differentiate on petrophysical logs.

\section{Distribution}

The Lutine Formation is widely present in the Central Graben (except in blocks F08 and F14), Step Graben, Schill Grund Platform and Terschelling Basin (Fig. 8b8). The formation grades partially into the Scruff Greensand Formation and Zurich Formation towards the south (southern Central Graben and Vlieland Basin). In the north the lateral equivalents of the Lutine Formation are the 'Hot Unit' of the Farsund Formation (Danish sector) and the Mandal Formation (Norwegian sector of the Central Graben; Michelsen \& Wong, 1991).

\section{Age}

Sequence 3 sensu Abbink et al. (2006): Ryazanian. The age of the base is diachronous; it has an Early Ryazanian age (runctoni Ammonite Zone) in the northernmost part of the Central Graben (B18 and F03 blocks) and is dated around the Early/Late Ryazanian boundary (kochi/icenii Ammonite zones, or younger) in the south.

\section{Depositional setting}

Basin circulation stagnated in the northernmost part of the basin, which resulted in dysoxic to anoxic basin-floor conditions and in the deposition and preservation of bituminous claystones. To the south relatively shallower, open marine circumstances occurred with (near) normal basin-floor ventilation. Overall the claystones are more silty or finely sandy and only slightly bituminous.

\section{Clay Deep Member (SGLUC), revised classification}

The member is defined by NAM \& RGD in 1980 and amended by Herngreen \& Wong (1989) and by Van Adrichem Boogaert \& Kouwe (1993; Fig. 1). Here, the Clay Deep Member is transferred to the new Lutine Formation, Scruff Group (Fig. 6). The Clay Deep Member was inappropriately classified in the Kimmeridge Clay Formation sensu Van Adrichem Boogaert \& Kouwe (1993), in spite of its chrono- and lithostratigraphic distinction from that formation. The lithology also evidently differs. The member lacks the well-developed dolomite stringers seen in the Kimmeridge Clay Formation, and tends to show higher GR-log readings. Note that the interval of the reference well B18-02 is restricted to interval 2225-2315 $\mathrm{m}$. The base interval 
2315-2355 $\mathrm{m}$ is transferred to the Scruff Greensand Formation (Fig. 11). Herngreen et al. (2000) showed that this low-GR section, in addition to the dating of 'latest Early Portlandian' at $2343 \mathrm{~m}$ depth, can be associated with the Scruff Greensand Formation. The correlation to well B18-03 verifies this interpretation (Fig. 11).

\section{Derivatio nominis}

Named after the Clay Deep, a sea-bottom depression situated at approximately $\mathrm{N} 55^{\circ}, \mathrm{E} 04^{\circ}$ in the Netherlands offshore.

\section{Type section}

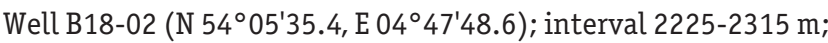
thickness: $90 \mathrm{~m}$ along hole (Fig. 11).

\section{Additional section}

Well F03-01 (N 54 59'40.0, E 04º54'18.0); interval 2265-2335 m; thickness: $70 \mathrm{~m}$ along hole (Van Adrichem Boogaert \& Kouwe, 1993, Annex G-3).

\section{Definition}

The member comprises (brownish-) grey to black claystones. The base of the Clay Deep Member is usually more silty. The claystones are generally rather bituminous, but locally less organic matter may be present.

\section{Lower boundary}

The Clay Deep Member rests unconformably on the undifferentiated Scruff Greensand Formation (block F03) or Kimmeridge Clay Formation (Fig. 6). The bituminous shales of the Clay Deep Member can be distinguished easily from the main Kimmeridge Clay Formation by their higher GR- and resistivity-log response. The contact with the Scruff Greensand Formation below is clear because of the change in lithology.

\section{Upper boundary}

The upper boundary coincides with the Sequence 3 / Sequence 4 transition sensu Abbink et al. (2006; Figs 2 and 6). It is associated with the Late Kimmerian unconformity. The member is covered (sometimes virtually conformably) by the Rijnland Group (or the Chalk or Lower North Sea Group). The boundary is shown by upwards decreasing values on the GR and the resistivity logs. The lithology changes towards sandy claystone/marl or limestone.

\section{Distribution}

The Clay Deep Member is restricted to the northern part of the Dutch Central Graben and Step Graben (blocks B18 to F08/F11). The organic matter content decreases to the south, where the Clay Deep Member grades into the Schill Grund Member (Fig. 6). The lateral equivalents of the Clay Deep are the 'Hot Unit' of the Farsund Formation (Danish sector, Michelson \& Wong, 1991) and the Mandal Formation (Norwegian sector of the Central Graben).

\section{Age}

Sequence 3 sensu Abbink et al. (2006): Ryazanian. The base of the Clay Deep Member is diachronous. It has an Early Ryazanian age (runctoni Ammonite Zone) in the northernmost part of the Dutch Central Graben (e.g. in the B18 and F03 blocks) and a Late Ryazanian age in the south. Characteristic dinoflagellate species are Batioladinium radiculatum, B. cf. varigranosum, Dingodinium spinosum (LOD: Late Ryazanian, albidum Ammonite Zone), Egmontodinium polyplacophorum, Gochteodinia virgula (LOD: Early Ryazanian, runctoni Ammonite Zone), Rotosphaeropsis thula and Systematophora daveyi. The agglutinated foraminifer Haplophragmoides cf. infracalloviensisis is regularly recorded.

\section{Palynofacies}

In addition to the occurrence of the dinocyst Gochteodinia virgula, the sporomorph spectra in the southern part of the B18 and F03 blocks are dominated by bisaccates and Classopollis, indicating arid conditions before the kochi climate shift. Higher in the successions the number of Classopollis decreases. These high concentrations of Classopollis in the assemblages are absent in the southern part of the northern Central Graben. Dinocysts include Daveya boresphaera, Dichadogonyaulax culmula, Dingodinium spinosum and Egmontodinium torynum, indicating a post kochi climate shift age. Most associations are characterised by common Structureless Organic Material (SOM). The SOM is associated with an anaerobic, relatively deeper (as compared to the Schill Grund Member) marine depositional environment.

\section{Depositional setting}

The Clay Deep Member was deposited in a shelf environment. Basin circulation stagnated which resulted in dysoxic to anoxic basin-floor conditions and in the deposition of bituminous claystones.

\section{Schill Grund Member (SGLUS), revised classification}

The member is defined by Van Adrichem Boogaert \& Kouwe (1993; Fig. 1). It was interpreted as the southern occurrence of the Clay Deep Member, but split off because of its slightly or non-bituminous character. Here the Schill Grund Member is transferred to the new Lutine Formation, Scruff Group. It was inappropriately attributed to the Kimmeridge Clay Formation sensu Van Adrichem Boogaert \& Kouwe (1993), because both units were separated by other members of the Scruff Greensand Formation. Furthermore, the lithology of the Schill Grund Member differs substantially from the Kimmeridge Clay Formation; the former lacks the well developed dolomite stringers.

\section{Derivatio nominis}

Named after the Schill Grund, a German name for the Scruff Bank in the North Sea. 


\section{Type section}

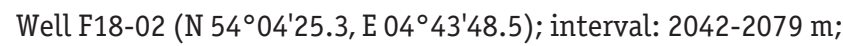
thickness: $37 \mathrm{~m}$ along hole (Appendix 2).

\section{Definition}

The member consists of olive-grey to grey-brown claystones. The claystones are non- to slightly calcareous, silty to very fine sandy, locally slightly bituminous, micaceous and pyritic.

\section{Lower boundary}

The Schill Grund Member is conformably underlain by the glauconitic Scruff Greensand Formation (Stortemelk Member in the southern Central Graben and Terschelling Basin, e.g. well F18-02; Fig. 6).

\section{Upper boundary}

The upper boundary coincides with the Sequence 3 / Sequence 4 transition sensu Abbink et al. (2006; Figs 2 and 6). It is associated with the Late Kimmerian unconformity. The member is covered (sometimes virtually conformably) by sediments of the Rijnland Group (or the Chalk or Lower North Sea Group). This boundary is shown by upwards decreasing values on the GR and the resistivity logs. The lithology changes towards argillaceous sandstone, sandy claystone/marl or limestone. The top is not always easy to pick on logs. Quite often, an intra Schill Grund 'kick' (Sequence 3) is mistaken for the base of the Rijnland Group (Sequence 4).

\section{Distribution}

The Schill Grund Member is limited to the southern part of the Dutch Central Graben, Schill Grund Platform and Terschelling Basin, e.g. blocks F12, F15, F17, F18, G13, G16, G17, L02, L03, L05, L06, M01, M04 and M07. The member may partially be a lateral time equivalent of the Stortemelk Member (Scruff Greensand Formation) and the Zurich Formation (Delfland Subgroup) along the southern margin of the Central Graben and into the Vlieland Basin. To the north the Schill Grund Member grades into the more bituminous clays of the Clay Deep Member.

\section{Age}

Sequence 3 sensu Abbink et al. (2006): Late Ryazanian, kochi/ icenii-albidum Ammonite zones. Diagnostic dinoflagellates are Batioladinium radiculatum, Daveya boresphaera, Egmontodinium torynum (LOD Late Ryazanian, albidum Ammonite Zone) and Oligosphaeridium diluculum (FOD: icenii Ammonite Zone). Characteristic microfaunal elements are the ostracods Galliaecytheridea teres, Mandelstamia sexti and Paranotacythere speetonensis. Cytheropterina eboracica was also found in the type section and has an FOD (= First 0ccurrence Datum) at the Ryazanian/Valanginian boundary.

\section{Palynofacies}

The palynomorph associations are well preserved and represent a normally oxygenated setting. Dinocyst assemblages are rich and diverse and characterised by i.e. Circulodinium compta, Gochteodinia villosa subsp. multifurcata, Hystrichodinium pulchrum, Kleithriasphaeridium porosispinum, Systematophora palmula and Tubotuberella apatela. The low diversity sporomorph assemblage is dominated by bisaccate pollen. This domination of bisaccates in addition to the high numbers and great variety of dinoflagellate cysts indicates an offshore open marine setting.

\section{Depositional setting}

Open-marine shelf conditions prevail. The slightly or nonbituminous nature of the sediments indicate near-normally oxygenated basin-floor circumstances.

\section{Concluding remarks}

New data and information from continued drilling in the shallow to non-marine Late Jurassic to Early Cretaceous successions in the northern Dutch offshore has become available to further study the complex geological setting. Together with new biostratigraphic techniques the need and opportunity arose to revise and update the Nomenclature of the Central Graben Subgroup and Scruff Group. New and reprocessed data and information on facies, changes in relative sea level, climate, ages and the recognition of three distinct genetic sequences bounded by well defined dis- and unconformities, allow the presentation of new lithostratigraphic relationships and names (see also Abbink et al., 2006). The present changes, based on consistent lithologic differences, more explicitly distinguished marine and non-marine conditions, refined datings and applied genetic sequences, simplify the overall nomenclature. The present revised and updated stratigraphic nomenclature of the Central Graben Subgroup and Scruff Group will help improve the reconstruction of the geological history and support hydrocarbon prospectivity studies in the northern Dutch offshore.

\section{Acknowledgements}

For the revision and update of the Callovian-Ryazanian Stratigraphic Nomenclature in the northern Dutch offshore, the authors want to express their gratitude to the involved organisations within the Dutch E\&P industry. These companies are: Centrica, Chevron, Cirrus, Dana Petroleum, Gaz de France Suez, Northern Petroleum, NAM, Total, Tullow Oil, Vermilion and Wintershall. Without their assignments, cooperation, providing subsurface data and sharing insights, this paper could not have been written. We are in particular indebted to Wintershall Noordzee B.V. and Gaz de France Suez E\&P Nederland B.V. for regularly enabling Late Jurassic studies in the northern Dutch offshore, during the past twenty years. PanTerra Geoconsultants 
and EBN are also thanked for their pleasant cooperation in several projects, focusing on the remaining hydrocarbon prospectivity of the Dutch Central Graben. The manuscript has greatly benefited from reviews by Peter Niels Johannessen (GEUS, Copenhagen, Denmark), Youri Poslawsky (GdF Suez E\&P Nederland B.V.) and Henk Kombrink (Total E\&P, Aberdeen, UK).

\section{References}

Abbink, O.A., 1998. Palynological investigations in the Jurassic of the North Sea region. PhD thesis, Utrecht University (Utrecht), $192 \mathrm{pp}$.

Abbink, O.A., Mijnlieff, H.F., Munsterman, D.K. \& Verreussel, R.C.M.H., 2006. New stratigraphic insights in the 'Late Jurassic' of the Southern Central North Sea Graben and Terschelling Basin (Dutch Offshore) and related exploration potential. Netherlands Journal of Geosciences 85: 221-238.

Andsbjerg, J. \& Dybkjær, K., 2003. Sequence stratigraphy of the Jurassic of the Danish Central Graben. Geological Survey of Denmark and Greenland Bulletin 1: 265-300.

Brown, S., 1990. Jurassic. In: Glennie, K.W. (ed.): Introduction to the Petroleum Geology of the North Sea. Blackwell (Oxford): 219-255.

Cameron, T.D.J., Crosby, A., Balson, P.S., Jeffery, D.H., Lott, G.K., Bulat, J. \& Harrison, D.J., 1992. The geology of the southern North Sea. United Kingdom offshore regional report. HMSO for the British Geological Survey (London), $152 \mathrm{pp}$.

Cariou, E. \& Hantzperque, P., 1997. Biostratigraphie du Jurassique ouest-européen et méditerranéen: zonations parallèles et distribution des invertébrés et microfossiles. Bulletin des Centres de Recherches Exploration-Production ElfAquitaine, Mémoire 17, $422 \mathrm{pp}$.

Costa, L.I. \& Davey, R.J., 1992. Dinoflagellate cysts of the Cretaceous System. In: Powell, A.J. (ed.): A Stratigraphic Index of Dinoflagellate Cysts. Kluwer Academic Publishers (Dordrecht): 99-154.

Coward, M.P., Dewey, J., Hempton, M. \& Holroyd, J., 2003. Tectonic evolution. In: Evans, D.J., Graham, C., Armour, A. \& Bathust, P. (eds): The Millennium Atlas: Petroleum Geology of the Central and Northern North Sea. The Geological Society (London): 17-33.

Davey, R.J., 1979. The stratigraphic distribution of dinocysts in the Portlandian (latest Jurassic) to Barremian (Early Cretaceous) of northwest Europe. American Association of Stratigraphic Palynologists, Contribution Series 5B: 48-81.

Davey, R.J., 1982. Dinocyst Stratigraphy of the latest Jurassic to Early Cretaceous of the Haldager No. 1 borehole, Denmark. Geological Survey of Denmark, Series B 6, 58 pp.

De Jager, J., 2007. Geological development. In: Wong, T.E., Batjes, D.A.J. \& De Jager, J. (eds): Geology of the Netherlands. Royal Netherlands Academy of Arts and Sciences (KNAW) (Amsterdam): 5-26.

Duin, E.J.T., Doornenbal, J.C., Rijkers, R.H.B., Verbeek, J.W. \& Wong, T.E., 2006. Subsurface structure of the Netherlands; results of recent onshore and offshore mapping. Netherlands Journal of Geosciences 85: 245-276.

Duxbury, S., Kadolsky, D. \& Johansen, S., 1999. Sequence stratigraphic subdivision of the Humber Group in the Outer Moray Firth area (UKCS, North Sea). In: Jones, R.W. \& Simmons, M.D. (eds): Biostratigraphy in Production and Development Geology. Geologicl Society Special Publication (London): 23-54.
Frandsen, N., Vejboek, O.V., Møeller, J.J. \& Michelsen, O., 1987. A dynamic geological model of the Danish Central Trough during the Jurassic-Early Cretaceous. In: Brooks, J. \& Glennie, K.W. (eds): Petroleum Geology of North West Europe. Graham \& Trotman (London): 453-468.

Fraser, S.I., Robinson, A.M., Johnson, H.D., Underhill, J.R., Kadolsky, D.G.A., Connell, R., Johannessen, P.N. \& Ravnås, R., 2003. Upper Jurassic. In: Evans, D., Graham, C., Armour, A. \& Bathurst, P. (eds): The Millennium Atlas: Petroleum Geology of the Central and Northern North Sea. The Geological Society (London): 157-189.

Gradstein, F.M., Ogg, J.G. \& Smith, A.G., 2004. A Geologic Time Scale 2004. Cambridge University Press (Cambridge), 589 pp.

Haq, B.U., Hardenbol, J. \& Vail, P.R., 1988. Mesozoic and Cenozoic chronostratigraphy and cycles of sea-level change. In: Wilgus, C.K., Hastings, B.S., Kendall, C.G.S.C., Posamentier, H.W., Ross, C.A. \& Wagoner, J.C.v. (eds): Sea level changes - an integrated approach. SEPM Special publications 42: 71-108.

Heilmann-Clausen, C., 1987. Lower Cretaceous dinoflagellate biostratigraphy in the Danish Central Trough. Danmarks Geologiske Undersøgelse 17: 1-90.

Herngreen, G.F.W., Kerstholt, S.J. \& Munsterman, D.K., 2000. CallovianRyazanian (Upper Jurassic) palynostratigraphy of the Central North Sea Graben and Vlieland Basin, the Netherlands. Mededelingen Nederlands Instituut voor Toegepaste Geowetenschappen TN0 63, 99 pp.

Herngreen, G.F.W., Kouwe, W.F.P. \& Wong, T.E., 2003. The Jurassic of the Netherlands. Geological Survey of Denmark and Greenland Bulletin 1: 217-229.

Herngreen, G.F.W., Smit, R. \& Wong, T.E., 1991. Upper Jurassic-Cretaceous stratigraphy of the Vlieland Basin, the Netherlands. In: Michelsen, 0. \& Frandsen, F. (eds): The Jurassic in the Southern Central Trough. Danmarks Geologiske Undersøgelse, Series B: 17-19.

Herngreen, G.F.W. \& Wong, T.E., 1989. Revision of the Late Jurassic stratigraphy of the Dutch Central North Sea Graben. Geologie en Mijnbouw 68: 73-105.

Johannessen, P.N., 2003. Sedimentology and sequence stratigraphy of paralic and shallow marine Upper Jurassic sandstones in the northern Danish Central Graben. Geological Survey of Denmark and Greenland Bulletin 1: 367-402.

Koch, J.O., 1983. Sedimentology of Middle and Upper Jurassic sandstone reservoirs of Denmark. Geologie en Mijnbouw 62: 115-129.

Kombrink, H., Doornenbal, J.C., Duin, E.J.T., Den Dulk, M., Van Gessel, S.F., Ten Veen, J.H. \& Witmans, N., 2012. New insights into the geological structure of the Netherlands; results of a detailed mapping project. Netherlands Journal of Geosciences 91-4: 419-446, this issue.

Lott, G.K., Wong, T.E., Dusar, M., Andsbjerg, J., Mönnig, E., Feldman-Olszewska, A. \& Verreussel, R.M.C.H., 2010. Jurassic. In: Doornenbal, J.C. \& Stevenson, A.G. (eds): Petroleum Geological Atlas of the Southern Permian Basin Area. EAGE Publications b.v. (Houten): 175-193.

Michelsen, O., Nielsen, L.H., Andsbjerg, J. \& Surlyk, F., 2003. Jurassic lithostratigraphy and stratigraphic development onshore and offshore Denmark. Geological Survey of Denmark and Greenland Bulletin 1: 147-216.

Michelsen, O. \& Wong, T.E., 1991. Discussion of Jurassic lithostratigraphy in the Danish, Dutch and Norwegian Central Graben Areas. In: Michelsen, 0. \& Frandsen, F. (eds): The Jurassic in the Southern Central Trough. Danmarks Geologiske Undersøgelse, Series B: 20-28.

NAM \& RGD, 1980. Stratigraphic nomenclature of the Netherlands. Verhandelingen van het Koninklijk Nederlands Geologisch Mijnbouwkundig Genootschap 32, $77 \mathrm{pp}$. 
Partington, M.A., Copestake, P., Mitchener, B.C. \& Underhill, J.R., 1993. Biostratigraphic calibration of genetic stratigraphic sequences in the Jurassic lowermost Cretaceous (Hettangian-Ryazanian) of the North Sea and adjacent areas. In: Parker, J.R. (ed.): Petroleum Geology of North-West Europe. Graham \& Trotman (London): 697-706.

Powell, A.J. (ed.), 1992. A Stratigraphic Index of Dinoflagellate Cysts. British Micropalaeontological Society Publication Series. Chapman and Hall (London), $290 \mathrm{pp}$.

Riding, J.B. \& Thomas, J.E., 1992. Dinoflagellate cysts of the Jurassic System. In: Powell, A.J. (ed.): A Stratigraphic Index of Dinoflagellate Cysts. Kluwer Academic Publishers (Dordrecht): 7-98.

Salvador, A., 1994. International stratigraphic guide. A guide to stratigraphic classification, terminology, and procedure, $2^{\text {nd }}$ edition. International Union of Geological Sciences and Geological Society of America, Inc. (Boulder, California), $214 \mathrm{pp}$.

Underhill, J.R. \& Partington, M.A., 1993. Jurassic thermal doming and deflation in the North Sea: implications of the sequence stratigraphic evidence. In: Parker, J.R. (ed.): Petroleum Geology of North-West Europe: Proceedings of the $4^{\text {th }}$ Conference. Geological Society (London): 337-345.

Van Adrichem Boogaert, H.A. \& Kouwe, W.F.P., 1993. Stratigraphic nomenclature of the Netherlands, revision and update by RGD and NOGEPA, Section A, General. Mededelingen Rijks Geologische Dienst 50: 1-40.

Wong, T.E., 2007. Jurassic. In: Wong, T.E., Batjes, D.A.J. \& De Jager, J. (eds): Geology of the Netherlands. Royal Netherlands Academy of Arts and Sciences (KNAW) (Amsterdam): 107-126.

Zanella, E. \& Coward, M.P., 2003. Structural framework. In: Evans, D., Graham, C., Armour, A. \& Bathurst, P. (eds): The Millennium Atlas: Petroleum Geology of the Central and Northern North Sea. The Geological Society (London): 45-59.

Ziegler, P.A., 1988. Evolution of the Arctic, North Atlantic and western Tethys. American Association of Petroleum Geologists Memoir 43, 198 pp.

Ziegler, P.A., 1990. Geological Atlas of Western and Central Europe (2nd edition). Shell Internationale Petroleum Maatschappij B.V.; Geological Society Publishing House (Bath), 239 pp.

\section{Appendix 1 - Well F15-02: type interval for the Scruff Greensand Formation and Scruff Spiculite Member}

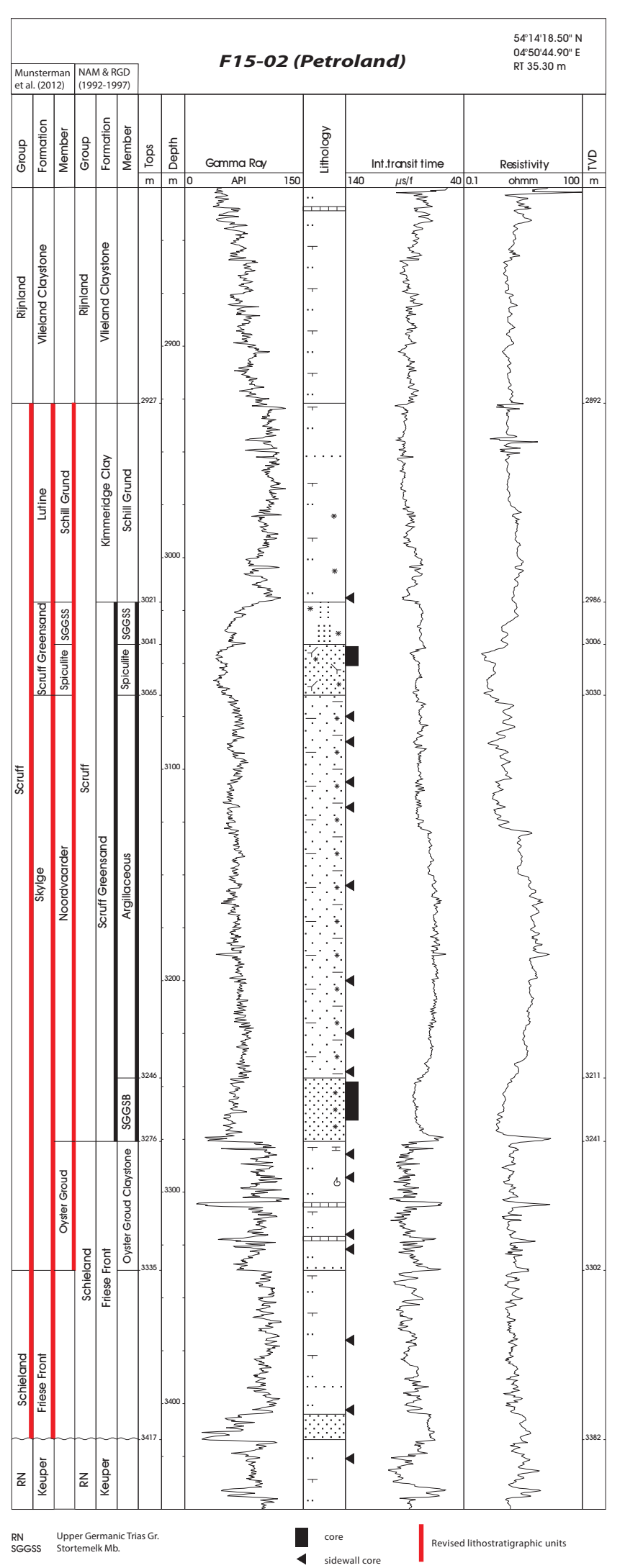


Appendix 2 - Well F18-02: type interval for Friese Front Formation, Oyster Ground Member, Stortemelk Member and Schill Grund Member

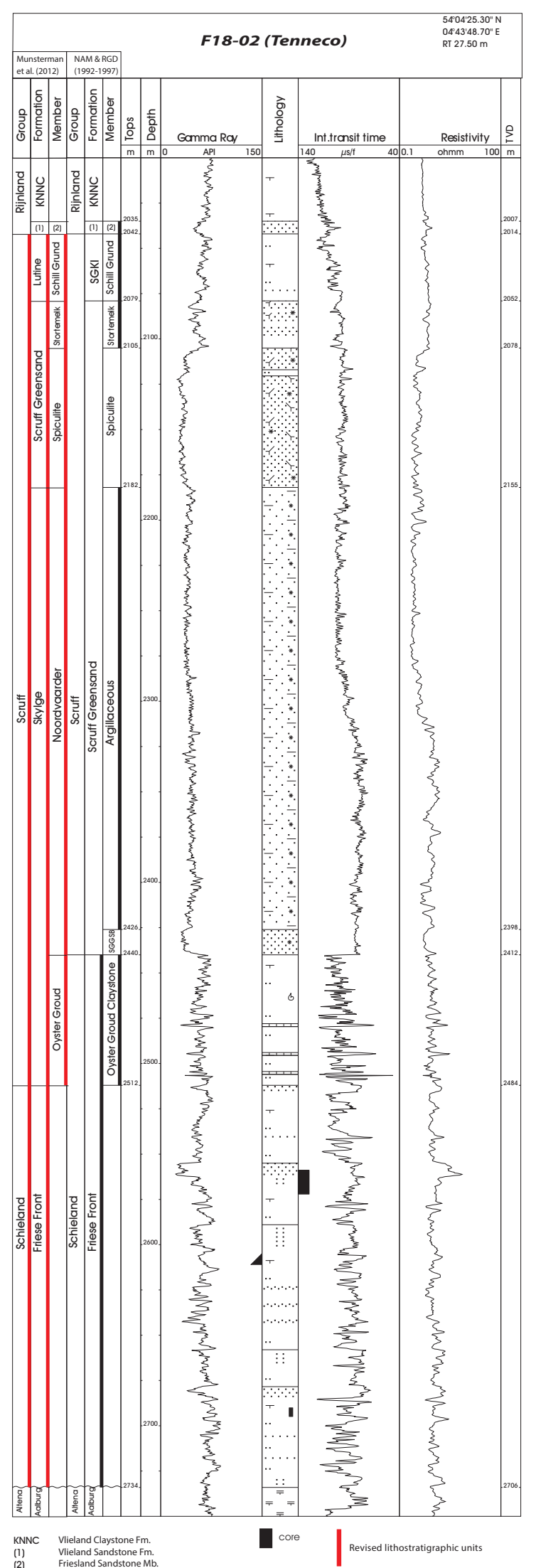

Appendix 3 - Well F18-01: reference section for the Scruff Greensand Formation and Scruff Spiculite Member

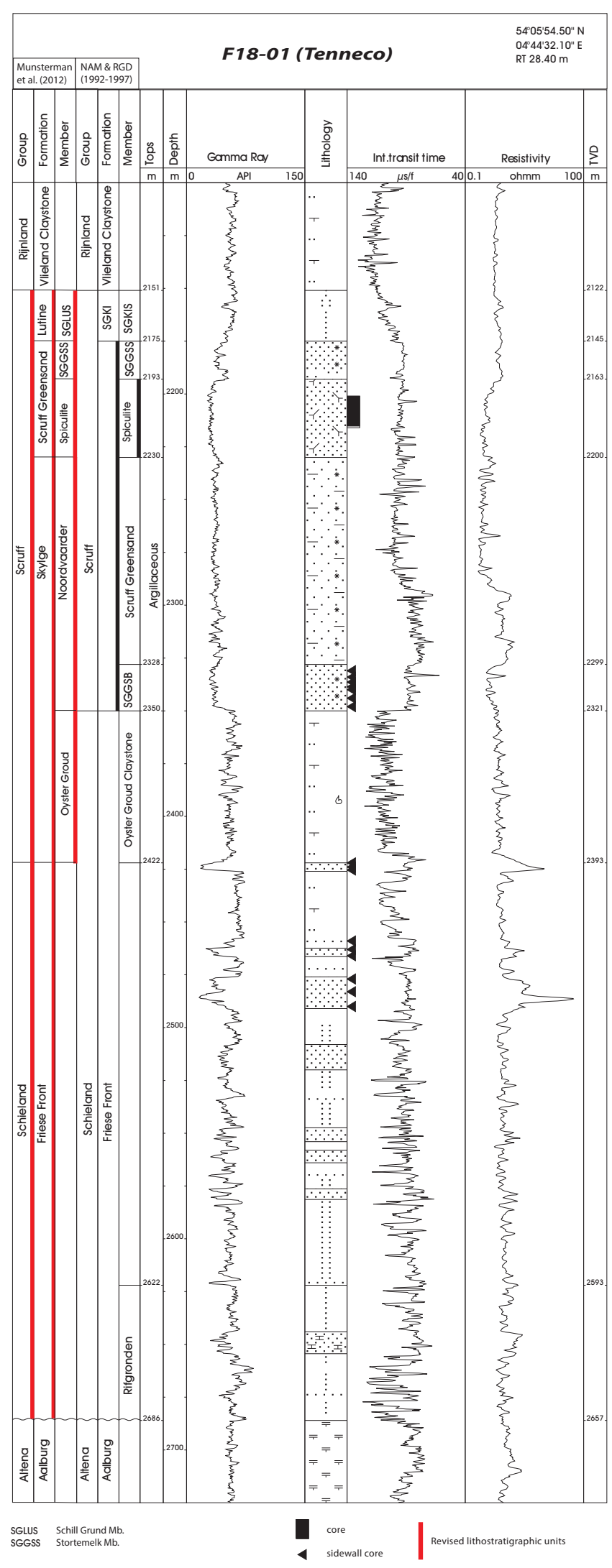

